NBER WORKING PAPER SERIES

\title{
INTERNATIONAL STANDARDS AND INTERNATIONAL TRADE: EMPIRICAL EVIDENCE FROM ISO 9000 DIFFUSION
}

\author{
Joseph A. Clougherty \\ Michal Grajek \\ Working Paper 18132 \\ http://www.nber.org/papers/w18132
NATIONAL BUREAU OF ECONOMIC RESEARCH
1050 Massachusetts Avenue
Cambridge, MA 02138
June 2012

Financial support from the German Federal Ministry of Education \& Research is gratefully acknowledged (project 01AK702A). We also thank Susanne Prantl, Lars-Hendrik Röller, Oz Shy, Christian Wey, and Eric van Wincoop, as well as seminar (Univ. of Illinois, ESMT Berlin, SFB in Berlin) and conference (EARIE in Porto and Ljubljana, Applied Infrastructure Research in Berlin, EEA in Amsterdam, ICT \& Economic Growth in Munich, ETSG in Athens, and the NBER Pre-Conference and Conference on "Patents, Standards, and Innovation") participants for helpful comments and discussions. Claudia Baldermann and Jennifer Rontganger provided excellent research assistance. All remaining errors, however, are our own. The views expressed herein are those of the authors and do not necessarily reflect the views of the National Bureau of Economic Research.

NBER working papers are circulated for discussion and comment purposes. They have not been peerreviewed or been subject to the review by the NBER Board of Directors that accompanies official NBER publications.

(C) 2012 by Joseph A. Clougherty and Michal Grajek. All rights reserved. Short sections of text, not to exceed two paragraphs, may be quoted without explicit permission provided that full credit, including (C) notice, is given to the source. 
International Standards and International Trade: Empirical Evidence from ISO 9000 Diffusion Joseph A. Clougherty and Michal Grajek

NBER Working Paper No. 18132

June 2012

JEL No. C51,F13,L15

\author{
effects. \\ Joseph A. Clougherty \\ University of Illinois at Urbana-Champaign \\ 350 Wohlers Hall \\ 1206 S. 6th Street, MC-706 \\ Champaign, IL 61820 \\ jaclough@illinois.edu \\ Michal Grajek \\ ESMT European School of \\ Management and Technology \\ Schlossplatz 1 \\ D-10178 Berlin \\ Germany \\ grajek@esmt.org
}

$\underline{\text { ABSTRACT }}$

Empirical scholarship on the standards-trade relationship has been held up due to methodological challenges: measurement, varied effects, and endogeneity. Considering the trade-effects of one particular standard (ISO 9000), we surmount methodological challenges by measuring standardization via national penetration of ISO 9000, allowing standardization to manifest via multiple (quality-signaling, information/compliance-cost, and common-language) channels, and using instrumental variable, multilateral resistance and panel data techniques to overcome endogeneity. We find evidence of common-language and quality-signaling augmenting country-pair trade. Yet, ISO-rich nations (most notably European) benefit the most from standardization, while ISO-poor nations find ISO 9000 to represent a trade barrier due to compliance-cost 


\section{Introduction}

Many trade scholars (e.g., Laird and Yeats 1990; Casella 1996; Deardorff and Stern 1998; Preeg 1998; Baldwin 2000) have observed that the substantial decrease in trade barriers over the last few decades has led to technical trade barriers (TTBs) - such as standards - becoming increasingly important determinants of international trade flows. Yet unlike tariffs and common non-tariff barriers (NTBs), standards have the potential to not only decrease but also expand trade. While international standards have been found to promote trade more than national standards (e.g., Blind 2001; Moenius 2004; Czubala, Shepherd and Wilson 2007; Shepherd $2007)^{1}$, they still have the power to be protectionist when consumers and large buyer groups require production according to these standards and compliance costs are relatively significant (Moenius 2006). Despite the recognized importance of the subject, there is almost universal agreement that we lack sufficient empirical evidence concerning the relationship between standards and trade (e.g., Matutes and Regibeau 1996; Maskus, Wilson and Otsuki 2000; Blind 2004; Moenius 2006). In this vein, Maskus, Wilson and Otsuki (2000: 45) state that "it is important to obtain as much information as possible about the quantitative implications of standards ... [for] ... trade prospects". Yet three challenges in particular have held back empirical scholarship on the international trade implications of standardization.

First, measurability difficulties represent a significant challenge that has curtailed efforts to successfully capture the impact of standards on trade. Deardorff and Stern (1998) note that standardization is one of the hardest NTBs imaginable to quantify - a lament echoed by many other studies (e.g., Laird and Yeats 1990; Maskus, Wilson and Otsuki 2000; Blind 2004; Shepherd 2007). In short, the evidence on standards does not necessarily come in a form that

\footnotetext{
${ }^{1}$ Swann, Temple and Shurmer (1996) represent an exception in that they found national standards to promote trade more than international standards.
} 
facilitates quantitative analysis. As a result, empiricists have tended to construct a simple count of the number standards - or the number of documents - in existence in order to capture the applicable degree of standardization in a nation or sector. Yet this inventory approach gives equal weight to all existing standards, and thus cannot differentiate between the effectiveness and significance of different standards (Laird and Yeats 1990; Swann, Temple and Shurmer 1996). Unfortunately, the pre-existing empirical literature appears to lack a natural and straightforward means to measure the intensity of standardization.

Second, the varied effects that standards potentially have make it difficult to identify the particular channels via which standards impact trade, hence empirical scholarship has often tended to elicit net effects. For one, the diffusion of standards can increase the competitiveness of a home-nation's products - signaling quality and safety - therefore leading to enhanced exports (Swann, Temple and Shurmer 1996; Blind 2001, 2004; Ganslandt and Markusen 2001). Further, the existence of standards in a host-nation can be favorable to trade as it provides crucial information to exporting firms on how to adapt a product for a particular market (Moenius 2004, 2006). Yet, host-nation standards may also be used in a protectionist manner to raise the costs of foreign competition (Boom 1995; Gandal and Shy 2001; Ganslandt and Markusen 2001). Such protectionist elements can be particularly strong when foreign firms face high adoption costs due in part to their having little influence on the standardization process (Maskus, Wilson and Otsuki 2000; Blind 2001). In addition, Bénézech et al. (2001) point out that standards also involve common-language elements that potentially facilitate exchanges between firms from different countries. For instance, Blind (2001) notes that corresponding-knowledge and absorptivecapacity in a country-pair yields efficient use of standards; and Moenius (2004) holds that bilaterally shared standards greatly enhance trade. In light of these multiple potential effects, it is 
no surprise that Maskus, Otsuki and Wilson (2004) observe a mixed empirical record with standards sometimes enhancing and sometimes impeding trade.

Third, endogeneity represents an additional challenge to the empirical literature on standards and trade, as the causal inferences concerning the impact of standardization may be inconsistent and biased. The potential for simultaneity between exports and trade barriers has been recognized for some time (e.g., Harrigan 1993; Trefler 1993; Lee and Swagel 1997), yet efforts to deal with endogeneity are a more recent phenomenon (e.g., Baier and Bergstrand 2002, 2007, 2009; Magee 2003). In particular, not only might international trade benefit from harmonization of standards due to decreasing trade barriers, but the standardization process might also in turn be determined by foreign trade intensity, as this indicates an economy's openness (Casella 1996; Blind 2002). In support of this conjecture, Moenius (2004) employs Granger testing and finds evidence of two-way causality between standards and trade volumes. As a consequence, empirical models of international trade using standardization as an explanatory variable may suffer from endogeneity bias. In addition, Santos Silva and Tenreyro (2006) point out that the parameters from log-linearized models (common in gravity trade equations) can also be misleading due to Jensen's inequality. Thus, endogeneity issues have also held back efforts to successfully capture in a consistent manner the impact of standards on international trade.

With the above issues in mind, we empirically investigate the impact of one particular international standard - ISO 9000 - on bilateral trade flows using a panel of cross-section timeseries data at five-year intervals from 1995-2005 for 91 nations. The ISO 9000 certification system for quality management represents the most successful standard - close to 777,000 worldwide certificates by 2005 - implanted by the International Organization for Standardization: a post-World War II Geneva-based international institution charged with developing standards to enhance global trade. The merits of studying ISO 9000's impact on trade reside beyond this being 
- by far - the most successful international standard in existence, as we can employ diffusion data (ISO 2002, 2006) to capture the degree to which the standard is adopted in a particular nation. We are able to move then beyond the customary inventory approach to measuring standardization, and instead consider the penetration of this seminal standard in a national environment. Furthermore, we can use home-nation and host-nation diffusion rates - and the interaction of the two - in order to identify the different channels via which standardization affects trade. Finally, we attempt to overcome the limitation of 'potential endogeneity' by employing panel-data procedures and instrumental variable (IV) techniques. In particular, we conduct estimations using first-differencing and country-pair fixed effects, multilateral resistance terms a la Baier and Bergstrand (2009), as well as estimations using ISO 14000 - a sister standard involving environmental procedures - as a potentially powerful and valid instrument. We also test for heteroscedasticity patterns in our estimated gravity equations in line with the Santos Silva and Tenreyro (2006) critique.

In addition to the above core methodological issues which we attempt to surmount, we will also consider the issue as to whether the EU potentially used ISO 9000 in a protectionist manner. The requirement of an EC Mark (a public safety standard based on ISO 9000) to gain access to European markets and the significant influence held by the EU in the International Organization for Standardization (where ISO 9000 was designed) suggest that ISO 9000 may have been employed by the EU as a device to enhance intra-European trade at the expense of imports from non-European nations. In particular, the trade barrier aspects of ISO 9000 are potentially more severe for developing nations as they often lack the infrastructure to support implementation of the standard (Maskus, Wilson and Otsuki 2000) and in turn exhibit relatively slower diffusion of ISO standards (Delmas 2002). Thus in line with the theoretical work by Gandal and Shy (2001), ISO 9000 may have been used to create a virtual standardization union. Accordingly, we will 
consider whether the worldwide diffusion of ISO 9000 has principally benefited European nations at the expense of non-European - particularly developing - nations.

The rest of the paper is organized as follows in order to support our analysis. Section II provides relevant background on the ISO 9000 standard and the data employed in the study. Section III considers the different channels via which standards may impact international trade flows. Section IV sets out the base gravity equation, discusses econometric issues, and presents initial empirical findings. Section V considers whether the benefits and costs of worldwide ISO 9000 standardization are evenly distributed among nations. Section VI concludes.

\section{Background on ISO 9000 Standard and Employed Data}

The main objective of the International Organization for Standardization is to harmonize worldwide standards in order to promote trade and thereby global welfare. To this end, ISO 9000 - as already noted - has been the most successful standard implanted by the International Organization for Standardization. The history of ISO 9000 started in 1987 with the publication of the ISO 9000 Quality Assurance Standards by a Technical Committee (TC 176) of the International Organization for Standardization. The standard spread to over 160 countries by the end of 2005, therefore solidifying its reputation as an international reference for quality requirements in business-to-business dealings (ISO 2002). Table 1 illustrates the rapid and successful worldwide penetration of this seminal standard by reporting the number of ISO 9000 certificates present in 2005 for each of the 91 countries from our sample.

In general, motivations behind the implementation of ISO 9000 could be divided into three main categories: i) compliance with government regulations, ii) ability to establish business relationships by meeting buyer requirements, and iii) internal efficiency gains. In fact, all the 
factors influencing managers to seek ISO 9000 certification - as identified by Anderson, Daly and Johnson (1999) in a comprehensive review of practitioner journals - fall into one of these three categories.

ISO 9000 adoption is a firm-based (or better said, premise-based) decision and firms strictly seek certification in their home countries. Each country has one government-designed accrediting agency that certifies the competence of third party registrars to conduct ISO 9000 quality audits - registrars are also charged with the issuing of certificates (Anderson, Daly and Johnson 1995, 1999). National-level governance of ISO certification enables our identification strategy - as explained later in the empirical section — and matters for the interpretation of results. For example, cross-national variation in institutional set-up, efficiency of administration and access to financing may result in the cost of acquiring ISO certification to vary substantially across the different countries in our sample. Such variation allows us to propose an instrumental variable for the level of ISO 9000 standardization that exploits different degrees of institutional quality - the suggestion being that countries suffering from poor-quality institutions face higher costs in adopting standards.

The ISO 9000 family of standards are often referred to as generic quality management standards, as they can be implemented by any organization regardless of its size, activity sector, or managerial/national culture. Quality management reflects what the organization does to enhance customer satisfaction by meeting buyer requirements and expectations (ISO 2002). Compliance with ISO 9000 indicates consistent use of documents and standardized procedures to produce a good or service. In other words, ISO 9000 certifies that a firm's products - for which a customer contracts - conform to specification. 
In our analysis, we treat ISO 9000 as a uniform standard even though it consists of a series of nested standards which evolved over time. Firms originally chose between three core certificates (ISO 9001, ISO 9002, and ISO 9003) that differed in terms of the covered quality system elements. The nested nature of these standards allowed firms to accommodate differences in the scope of their operations. ${ }^{2}$ The 2000 edition of the ISO 9000 family replaced these three standards with a single standard labeled ISO 9001:2000. As supplementary standards, the 2000 edition included ISO 9000:2000, which describes fundamentals and specifies vocabulary for a quality management system, and ISO 9004:2000, which provides guidelines for performance improvements. Both of these standards (ISO 9000:2000 and ISO 9004:2000) were developed on the basis of previous ISO standards. Given that the core members of the ISO 9000 family were finally replaced by a single standard, the simplifying assumption of this paper treating ISO 9000 as a uniform standard seems justified, and has been practiced in the literature (e.g., Guler, Guillén and Macpherson 2002; Prakash and Potoski 2006, 2007; Terlaak and King 2006).

Accordingly, data for our empirical analysis is compiled from the International Organization for Standardization (ISO 2002, 2006) as well as from other sources such as the UN's Comtrade and the World Bank's World Development Indicators. We construct a panel (for every five years) from 1995-2005 of the bilateral trade flows and standard gravity equation variables among 91 potential trading partners (an actual 7,346 country-pairs with usable data) ${ }^{3}$, and then match these data with ISO 9000 diffusion rates for the 91 nations over the same period: the respective national certification counts for ISO are reported in Table 1. We use five-year time intervals in order to tease out long-term effects rather than short-term adjustments - a common

\footnotetext{
${ }^{2}$ See Anderson, Daly and Johnson (1995, 1999) for details.

${ }^{3}$ Note that we define the country-pair as exporter-importer specific; for instance, US-Canada and Canada-US are two distinct country-pairs.
} 
approach in the international trade literature (e.g., Frankel and Wei 1997a; Rauch and Trindade 2002; Baier and Bergstrand 2007). In the time dimension, the sample is restricted to just three years $\left(1995,2000\right.$ and 2005) due to availability of instruments. ${ }^{4}$ Yet in the cross-section dimension, the sample is fairly large: covering approximately $80 \%$ of worldwide trade, and $99 \%$ of worldwide ISO 9000 adoptions. An advantage of the wide sample is that less developed nations - where the trade barrier elements may manifest - are included; hence, the generality of our results will not suffer then from selection bias.

Table 2 lists all variables used in the estimations along with their definitions, sources, and descriptive statistics. Exports, GDP, population, and distance follow standard definitions used in gravity models. For the sake of international comparability, the ISO 9000 variable is constructed in relation to a nation's population. ${ }^{5}$ The ISO 14000 variable is treated in the same way. The infrastructure index is a simple average of road density, air passengers per capita, and telephone lines per capita—all of which are likely to reduce home-nation and host-nation trade costs (Carrère 2006). Finally, the FTA variable from Baier and Bergstrand (2007) - further developed by Jeffrey Bergstrand - covers all free trade agreements worldwide until $2005 .^{6}$

The developers of ISO 9000 envisioned that "through world-wide acceptance and use, the ISO 9000 family of standards will provide an effective means for improving the performance of individual organizations and providing confidence to people and organizations that products

\footnotetext{
${ }^{4}$ ISO 14000 represents the main instrument for ISO 9000 - see the description in Section IV.B - and is unavailable prior to 1995-the year of its initiation.

${ }^{5}$ Because empirical gravity equations employ the logs of variables, we add 1 to the number of ISO 9000 certificates in a nation - before taking the logarithm of (ISO certificates / population) - in order to avoid losing observations when the number of certificates in one of the trading nations equals zero. Note also that the reported results are robust to using GDP as a denominator; however, population is less subject to endogeneity than is GDP.

${ }^{6}$ The FTA variable has been obtained from the Database on Economic Integration Agreements (downloadable from http://www.nd.edu/ jibergstr) and is defined as a Preferential Trade Agreement or common membership in a Free Trade Area, a Customs Union, a Common Market, or an Economic Union.
} 
(goods and services) will meet their expectations thereby enhancing trade, global prosperity and individual well-being" (ISO 2005: 4). In line with this aim, some scholarship has proposed that the adoption of ISO 9000 certificates enhances international trade (e.g., Hudson and Jones 2003; Clougherty and Grajek 2008). We now turn to how ISO 9000 - and international standards in general - may have varied effects on trade between nations.

\section{Varied Trade Effects of Standardization}

As noted in the introductory comments, standardization can affect international trade flows via a variety of channels. In order to begin to break down the net effect of standardization into composite effects, we will concentrate here on three particular channels: 1) an enhancedcompetitiveness effect captured by home-nation standardization; 2) a combined information/compliance-cost effect captured by host-nation standardization; 3) a commonlanguage effect captured by the interaction of home-nation and host-nation standardization.

First, diffusion of standards in a home-nation environment can yield a competitive advantage for national firms that leads to augmented exports. This enhanced competitiveness dynamic may be due to internal efficiency gains and quality improvements on the part of firms adopting standards (Swann, Temple and Shurmer 1996). For example, Anderson, Daly and Johnson (1999) report average annual savings of $\$ 200,000$ for a mid-sized US firm due to ISO certification. These internal gains would seemingly influence firms' general competitiveness and thereby influence trade flows. In light of the fact, however, that ISO certification also involves an implementation cost - Blind (2004) estimates it to be between $\$ 50,000$ and $\$ 250,000-$ it is no surprise that firms with good pre-existing quality systems may find ISO 9000 to generate internal 
losses due to the added costs, delays, and burdensome documents necessary for certification (Terziovski, Power and Sohal 2003).

Since internal firm benefits may likely be minimal, most scholarship keys upon external firm benefits as the principal dynamic via which standardization enhances the competitiveness of exports (Hudson and Jones 2003). For instance, Blind (2004) notes that minimum quality standards - like ISO 9000 - can substantially reduce transaction and search costs. In particular, ISO 9000 not only proxies for conformance of the firm's product to its specification, but can also signal a firm's superior but unobserved attributes. In line with this argument, Terlaak and King (2006) find ISO certification to increase facility growth when buyers face multiple suppliers and the attributes of suppliers are intangible. Furthermore, Clougherty and Grajek (2008) find ISO certification to facilitate trade in developing nations where established institutional frameworks to detect quality-valuing firms are lacking. In short, ISO 9000 potentially offers a low-cost signal of a firm's commitment to quality that alleviates information asymmetries and transaction costs and can thus lead to enhanced exports when the standard is diffused widely in a home-nation.

Second, diffusion of standards in a host-nation can involve two countervailing effects - an information effect and a compliance-cost effect - that impact international trade flows (Moenius 2004, 2006). In terms of the information effect, the adoption of a standard by a nation represents a mechanism via which local knowledge is disseminated and more easily available to foreign firms, therefore providing information on the necessary criteria for selling in a national market (Swann, Temple and Shurmer 1996). This dynamic creates obvious export opportunities for foreign firms as transparency and clarity are enhanced and the cost of acquiring information regarding the host-nation environment is reduced. For example, the mass adoption of ISO 9000 in a target environment represents an efficient improvement for exporters when compared with a situation where each customer specifies unique quality-control requirements. 
However, the diffusion of standards in a host-nation environment can also hinder trade if this induces substantial compliance costs on the part of foreign producers (Moenius 2006). In order to become certified, foreign producers must adapt manufacturing design, reorganize production systems, and comply with multiple certification and testing procedures (Brenton, Sheehy and Vancauteren 2001). These compliance costs have been found to be substantial for middle- to smaller-sized firms (Hanson 2005) and for firms hailing from developing nations (Maskus, Wilson and Otsuki 2000; Czubala, Shepherd and Wilson 2007). Thus bearing out Blind's (2001) observation that adaptation costs may be particularly high for those firms with no influence on the standardization process. Accordingly, the implantation of a standard in a hostcountry environment can adversely affect foreign producers by increasing their compliance costs, and hindering trade when these adaptation costs are substantial. In sum, adoption of the ISO 9000 standard in the host-nation environment involves two countervailing effects (a positive information effect and a negative compliance-cost effect); thus, the net-effect depends upon whether the trade-fostering elements outweigh the trade-hindering elements.

Third, standards have also been noted to have common-language properties that facilitate cross-firm communication. Blind (2001) points out that corresponding technical knowledge on both ends of a country-pair is essential to enhance the efficiency of communication and promote cross-border trade; i.e., the standard must be adopted in both the home and host nation in order to establish a common-language. Furthermore, a number of scholars (Casper and Hancké 1999; Dissanayaka et al. 2001; Clougherty and Grajek 2008) have argued that ISO 9000 involves such properties, as the certificate can establish a means to communicate the nature of internal production systems to buyers and provide a cross-organizational procedural language in businessto-business dealings. Bénézech et al. (2001: 1396) summarize this point when stating that "the ISO 9000 series can be viewed as a code, a language used by firms". The standardized 
documentation flow and organizational procedures within ISO certified firms naturally lowers information asymmetries between firms, which in turn leads to lower transaction and search costs in vertical relations. Yet to fully realize the benefits of ISO 9000, both contracting parties should have adopted (i.e., learned) it in the first place; hence, the appropriateness of the commonlanguage analogy. In short, the common-language properties of ISO 9000 can reduce the communication frictions endemic to trade relations between firms from different nations by allowing the ready communication of internal production systems.

This common-language dynamic has elements in line with the literature strand considering the role of networks in reducing the information costs associated with international trade (e.g. Rauch 1999; Rauch and Trindade 2002). Rauch and Trindade (2002) note that via matching buyers and sellers in characteristics space, networks may considerably impact trade flows, since inadequate information about opportunities represents a substantial informal barrier to international trade. To the extent that ISO 9000 promotes a like-minded community with lower internal information and search costs, its role for trade resembles the role of ethnic Chinese networks (Rauch and Trindade 2002) and the internet (Freund and Weinhold 2004). Accordingly, our work partly follows through on Rauch's (1999) observation that the network/search view of international trade opens up space for greater consideration of the role played by contacts and relationships in determining the geographic distribution of economic activity. In our case, learning the common language of ISO 9000 could be viewed as an alternative to establishing vertical relations based on long-term interactions and a reputation for trust.

In sum, we consider the ability of ISO 9000 standards to impact international trade flows via three principal channels. First, diffusion of ISO 9000 standards in the home-nation can promote country-pair exports: an enhanced competitiveness effect. Second, diffusion of ISO 9000 in the host-nation can either promote or hinder country-pair exports: depending on whether the 
information effect outweighs the compliance-cost effect. Third, combined diffusion of ISO 9000 in both the home and host nation can promote country-pair exports: a common-language effect. In order to account for these different effects, we employ the number of ISO certificates relative to population to capture the standard's penetration in a nation, and then introduce these measures for exporting and importing countries (ISO adoption for the home-nation, host-nation, and interaction of home and host nations) into a country-pair export equation. The interaction term's identification of the common-language effect is very helpful, as otherwise common-language properties would manifest via the individual home-nation and host-nation ISO variables.

\section{Estimating the Trade Effects of ISO 9000}

\subsection{Model selection and estimation issues}

The standard empirical framework used to predict trade flows is a gravity equation, which merely states that bilateral flows are proportional to the economic masses of the trading parties and inversely proportional to the distance - or more generally trade barriers - between them. Its attractiveness stems from a strong theoretical background and a long record of empirical studies yielding robust results. Empirical studies employing versions of the gravity equation began with Tinbergen (1962) and Linnemann's (1966) seminal contributions; and the theoretical foundations include Anderson (1979), Bergstrand (1985), Helpman and Krugman (1985), Deardorf (1998) and more recently Eaton and Kortum (2002) and Anderson and van Wincoop (2003).

To analyze the problem at hand, we allow ISO 9000 diffusion in both home and host nations to affect exports within a standard gravity equation set-up of the following fashion: 


$$
\begin{aligned}
\ln \operatorname{Exp}_{i j t} & =\alpha_{0}+\alpha_{1} \ln G D P_{i t}+\alpha_{2} \ln G D P_{j t}+\beta_{1} \ln P O P_{i t}+\beta_{2} \ln P O P_{j t}+ \\
& +\gamma_{1} \ln I S O 9000_{i t}+\gamma_{2} \ln I S O 9000_{j t}+\delta_{1} \ln I n f r_{i t}+\delta_{2} \ln I n f r_{j t}+ \\
& +\ln t_{i j t}+\lambda_{t}+\varepsilon_{i j t},
\end{aligned}
$$

where the subscripts $i, j$ and $t$ stand for home-nation, host-nation, and year respectively. First off, the economic masses involved with a particular country-pair are captured by the GDP and the population for both the home and host nation. We also add home and host ISO 9000 diffusion, as well as a measure of home and host infrastructure development into the gravity equation. ${ }^{7}$ All of these constructs are specific to a particular country, thus they involve multilateral effects. In addition to these multilateral constructs, our gravity equation also explicitly accounts for bilateral (i.e., country-pair specific) trade costs, which we measure as:

$\ln t_{i j t}=\phi_{1} \ln$ Distance $_{i j}+\phi_{2} F T A_{i j t}+\phi_{3} \ln \left(I S O 9000_{i t}\right) \ln \left(I S O 9000_{j t}\right)$,

where Distance reflects the geographic distance between the trading partners, FTA stands for the presence of a Free Trade Agreement, and the potential complementarities of ISO 9000 are captured by the interaction of home-nation and host-nation ISO diffusion.

Accordingly, our baseline gravity regression equation follows the prescriptions given by Maskus, Wilson and Otsuki (2000) concerning a robust and useful equation to elicit the impact of standardization on trade: where GDP, population, geographical distance, and FTA presence all represent essential constructs. Our gravity equation also explicitly controls for a few additional factors. First, we control for the impact of any time-specific effects - e.g., world income trends in the data series with year dummies $\left(\lambda_{\mathrm{t}}\right)$. Second, we account for a potentially heteroscedastic and autocorrelated error term $-\varepsilon_{i j t}$ - by using cluster-robust standard errors in the estimations:

\footnotetext{
${ }^{7} \mathrm{We}$ control for the impact of the physical infrastructure held by trading partners via home and host nation infrastructure indices, as physical infrastructure is likely to be positively correlated with soft infrastructure like ISO 9000. Thus, neglecting such drivers of trade might bias the ISO 9000 coefficient estimates upward.
} 
where clusters are defined as country-pairs. We also follow Santos Silva and Tenreyro's (2006) recommendation to test for specific heteroscedasticity patterns in estimated gravity equations. ${ }^{8}$ While these properties describe well the estimation procedures for the baseline gravity equation model, two other econometric/modeling issues should be considered in order to generate robust causal inferences: 1) panel-data techniques; 2) multilateral resistance terms. These two issues directly lead to several regression models that we will estimate in addition to the base gravity equation.

First, our base gravity equation does not explicitly account for an array of other factors affecting trade which have been identified in the literature: e.g., currency unions, colonial history, common language, common border, and ethnic networks. To the extent that these trade-drivers do not vary over time, these factors can be controlled for by means of country-pair specific fixedeffects (FE) estimations or by first-differencing (FD) estimations. Given the relatively short time span of our sample, most of these factors are indeed time invariant. Therefore, using FE and FD or more generally panel-data estimation techniques - has an additional advantage of accounting for trade related factors that are difficult to quantify or observe: e.g., institutional environment, information costs, and cultural proximity. This is important, since omitted variables can result in endogeneity problems and bias estimates (Wooldridge 2002: 61-63). For instance, one might expect ISO 9000 diffusion to be supported by a nation's well-functioning institutions, but institutions are also likely to support trade (Anderson and Marcouiller 2002); hence, neglecting institutions in a gravity equation may lead to an upward bias in the estimated ISO 9000 coefficients. For example, Baier and Bergstrand (2007) make great use of country-pair specific

\footnotetext{
${ }^{8}$ Consistent with what they found, our tests point to the fact that heteroscedasticity in the pooled OLS regressions (i.e., without country-pair fixed effects) leads to inconsistent coefficient estimates in the log-linearized gravity model. Yet in the fixed-effects regressions, the heteroscedasticity tests show that log-linearization does not invalidate the consistency of our estimates.
} 
effects in order to deal with FTA endogeneity when domestic policies are omitted variables. In short, country-pair fixed effects and first-differencing control for many potential sources of endogeneity by accounting for all observed and unobserved time invariant factors, thus it behooves us to undertake such estimations.

Second, we also move beyond FE and FD by estimating a gravity equation controlling for “multilateral resistance terms", as derived in Anderson and van Wincoop's (2003) theoretical underpinning for the gravity equation. As shown in their model, the trade flows between any two countries are shaped by the bilateral trade costs $t_{i j t}$ between every possible country-pair due to general equilibrium effects. As a consequence, a proper gravity equation should be augmented by multilateral resistance terms to capture these effects. The estimation of this theory-backed gravity equation proved computationally burdensome, however, as it requires estimating and solving a non-linear system of equations. One means to overcome this challenge is to introduce countryand-time-specific effects (Anderson and van Wincoop 2003; Feenstra 2004). ${ }^{9}$ Although computationally less involved, this method has the drawback that virtually all explanatory variables (i.e., the multilateral constructs in our regression specification) will be collinear with the country-and-time-specific effects; hence, the coefficient estimates for these explanatory variables will not be identified. In particular, we would be unable to estimate the GDP, ISO 9000, and infrastructure coefficients for home and host nations in our empirical context. In addition, the introduction of country-and-time-specific effects does not allow for straightforward computation of general equilibrium effects, as it would still require solving a non-linear system of equations. ${ }^{10}$

\footnotetext{
${ }^{9}$ In a panel data model, one has to allow the country-specific effects to vary over time in order to capture varying multilateral price terms.

${ }^{10}$ We use this method merely as a robustness check for the common-language coefficient in our gravity equation.
} 
Baier and Bergstrand (2009) recently proposed a method to circumvent the above problems by expanding the multilateral resistance terms via the use of a simple first-order loglinear Taylor-series approximation. This approach allows for consistent OLS estimation of the bilateral trade cost function $t_{i j t}$ in a gravity equation since the theory-driven multilateral-resistance terms enter the gravity equation linearly. Another advantage to this approach is that it readily allows estimating both the partial effects and the total effects (i.e., the general equilibrium effects) for the various bilateral trade-cost measures: $t_{i j t}$. As already noted, general equilibrium effects would otherwise require estimating and solving a non-linear system of equations. Since ISO 9000 manifests both bilaterally (the common-language effect) and multilaterally (the home and host effects) in our gravity specification, the Baier and Bergstrand (2009) method is particularly well suited for our empirical context. See the appendix for the construction of the theory-driven multilateral-resistance terms for our gravity trade equation.

It also bears reiterating that ISO 9000 may affect international trade flows via different channels; hence, the three different ISO variables inserted into the gravity equation help identify these different channels. A positive coefficient estimate for home-nation ISO diffusion can indicate higher efficiency or better quality-signaling on the part of home exporters. A negative (positive) coefficient estimate for host-nation ISO diffusion indicates that the compliance-cost (information) effect is relatively strong. Finally, a positive coefficient estimate for the interaction of home and host diffusion would indicate the presence of common-language properties regarding ISO 9000 adoption. And as outlined above, we will estimate the proposed regression model by six different means: a standard baseline OLS estimation, a country-pair fixed effects estimation, a first-differencing estimation; and then three identical specifications (baseline OLS, fixed effects and first differencing) where multilateral resistance terms estimations a la Baier and Bergstrand (2009) are layered on. 


\subsection{Instrumenting for ISO 9000 Diffusion with ISO 14000}

While the six estimations noted above are conscious of the potential for endogeneity, it behooves us to more directly address the endogeneity issue due to its potential significance. Baier and Bergstrand's (2007) review of the endogeneity problem in the context of gravity equations highlights the general importance of endogeneity issues in empirical models of international trade; yet as they point out, these efforts have largely concentrated on the endogeneity of income. Simultaneity between GDP and trade flows could arise as a nation's GDP is a function of its exports via national income accounting. Empirical studies of trade, however, typically find an insignificant endogeneity bias for GDP coefficients (Hummels and Levinsohn 1995; Frankel and Wei 1997b). Frankel and Wei (1997a: 79) summarize this point well when they state "evidently, the endogeneity of income makes little difference". The potential endogeneity of ISO 9000 diffusion, on the other hand, poses a more serious problem for our analysis.

The simultaneity issue is particularly germane to our context as standardization may indeed determine trade, yet trade may also determine standardization. As pointed out in the literature, higher trade levels indicate an economy's openness and can thus stimulate adoption of international standards (Casella 1996; Blind 2002). For instance, in an investigation of factors determining standardization in twenty industrial sectors for seven countries, Blind (2002) reports evidence supporting a positive relation between export-orientation (the ratio of exports to total production) and standardization-intensity (the stock of national and international standards). Recall also the work by Moenius (2004) supporting two-way causality between standards and trade. In our particular context, ISO 9000 adoption has been posited to be a function of trade volumes: for instance, Hanson (2005) notes that a virtual requirement for exporting to the $\mathrm{EU}$ is 
the obtainment of a CE marking - a mark that is based on the ISO 9000 system. Consequently, one might expect that reverse-causality would bias the coefficient estimate for home-nation standardization upward. Generally, however, the direction of bias in our model is less clear due to the inclusion of the interaction term that captures the common-language effect. In any case, if one wants to elicit a robust relationship between ISO 9000 and trade, then one must account for possible simultaneity. Yet, the few empirical studies considering the impact of standards on trade do not tend to address the simultaneity issue.

Beyond the potential for simultaneity to create endogeneity bias, reside two additional common sources of endogeneity: omitted variables and measurement error (Wooldridge 2002: 51). The previously noted country-pair fixed effects, first-differencing, and multilateral resistance estimations go a long way to addressing concerns owing to omitted variables; thus, we largely follow here Baier and Bergstrand's $(2007,2009)$ respective approaches to address endogeneity issues via the strengths of a panel-data approach and via the inclusion of theoretically-motivated exogenous multilateral resistance terms. With regard to measurement error as a source of endogeneity, it bares noting that our key explanatory variables regarding ISO 9000 represent continuous constructs and not the dichotomous constructs that are often more subject to endogeneity. As Baier and Bergstrand (2007: 80) state "the best method for eliminating this bias [measurement error] is construction of a continuous variable that would more accurately measure". Finally, endogeneity bias may arise from an oft neglected source; i.e., log-linearization of the gravity equation with heteroscedasticity patterns in the error term (Santos Silva and Tenreyro, 2006). We will test for heteroscedasticity in order to rule out this source of endogeneity bias.

While we carry these features - country-pair fixed effects and multilateral resistance terms - forward for our current empirical analysis, we can go deeper now in treating potential 
endogeneity by further addressing the issue of simultaneity between standards-intensity and trade flows, as this appears to be the most-relevant potential source of endogeneity remaining in our gravity trade equations. In particular, we will improve upon the important panel-data enabled and multilateral-resistance terms based features of our analysis by layering on instrumental variable (IV) techniques. Hence, the combination of these approaches allows us to thoroughly control for endogeneity. While IV techniques have been previously employed in the trade literature to deal with endogeneity (e.g., Magee 2003; Baier and Bergstrand 2002), the impediment of identifying suitable instruments that are correlated with the explanatory variable but uncorrelated with the unobservables that impact bilateral trade has largely held up this approach (Baier and Bergstrand 2007). Yet we are fortunate to have an available and suitable instrument that allows tackling the simultaneity issue via the application of IV techniques in order to purify the ISO 9000 diffusion variables of the stochastic disturbance term and converge on a true coefficient estimate. Namely, we employ data on ISO 14000 diffusion to instrument for ISO 9000 diffusion.

ISO 14000 is a voluntary environmental standard covering management tools and systems aimed at monitoring and improving the environmental performance of a firm. What makes ISO 14000 such a good instrument for ISO 9000 are conditions of infrastructural convenience in terms of the common elements between the two standards. In particular, the penetration of ISO 9000 in a nation is likely to be positively correlated with ISO 14000 penetration due to the common presence of the appropriate institutions via which a firm can seek both ISO 9000 and 14000 qualification. ${ }^{11}$ In fact, there exists empirical evidence that the number of ISO 14000 certifications is very positively related to the number of ISO 9000 certifications, consequently suggesting that the drivers behind the two have significant overlap (Corbett and Kirsch 2001; Vastag 2004). Moreover, the penetration of ISO 14000 in a nation is likely to be driven by the

\footnotetext{
${ }^{11}$ As discussed in the second section, the ISO certification process is governed at the national-level—which makes it dependent on the availability and quality of domestic institutions.
} 
stringency of a country's environmental policies rather than by trade orientation, since ISO 14000 principally helps firms conform to environmental standards at the point of production (i.e., it is based on home-nation not foreign-nation pressure). Accordingly, it is unlikely that ISO 14000 adoption is correlated with the error term in the trade equation. In addition, Prakash and Potaski $(2006,2007)$ find corroborating evidence in that the number of national ISO 9000 certificates significantly impacts the number ISO 14000 certificates, but export-orientation does not impact the number of ISO 14000 certificates in a nation. Hence, high levels of trade per se do not appear to significantly affect ISO 14000 certifications, thus corroborating our prior that ISO 14000 represents a good instrument.

\subsection{Discussion of the results}

Table 3 incorporates the econometric/modeling issues outlined above by reporting six different regression specifications. Regression 1 reports the results from the baseline gravity equation; Regression 2 the results employing country-pair specific fixed-effects; and Regression 3 the results employing first-differencing; Regression 4 the results from the baseline gravity equation with multilateral-resistance terms; Regression 5 the results employing country-pair specific fixed-effects with multilateral-resistance terms; Regression 6 the results employing firstdifferencing with multilateral-resistance terms. The six different regression specifications allow detecting whether our main findings are generally robust. Furthermore - and in keeping with our efforts to layer IV techniques on top of panel-data features - Table 4 reports results where we replicate the six regression equations from Table 3 while employing IV estimation techniques for the three ISO variables: home-nation, host-nation, and home-host interaction. 
The results reported in Tables 3 and 4 are generally consistent with the pre-existing empirical trade literature. The coefficient estimates for the main drivers behind the gravity forces - home-nation and host-nation GDP - in the pooled OLS estimations (Regressions 1 and 4) correspond well to the standard results in the literature (e.g. Frankel and Wei 1997b: Table 6.5ab; Baier and Bergstrand 2007): i.e., the elasticity of exports with respect to GDP (both home and host) is close to $1 .{ }^{12}$ Additionally, the home and host GDP coefficient estimates in the FE and FD panel estimations (Regressions 2, 3, 5 and 6) are higher than the coefficient estimates in the OLS estimations - a result which also conforms with previous work (e.g. Carrère 2006; Baier and Bergstrand 2007). Furthermore, the coefficient estimates for the population variables are positive in the OLS estimations, and negative in the panel estimations. While the coefficient estimates for population are generally expected to be positive, it is not uncommon to find the opposite sign in empirical estimations of gravity equations (e.g. Frankel and Wei 1997b: Tables 6.3 and 6.5a-b). ${ }^{13}$

The results regarding the infrastructure variables also conform to expectation, as the coefficient estimates are positive and significant in the pooled OLS estimations (Regressions 1 and 4) in Tables 3 and 4. Moreover, the magnitude of these effects is quite significant, as the elasticity of exports with respect to both home and host infrastructure varies between 0.10 and 0.25 - comparable levels to the results reported in Carrère (2006). The infrastructure variables are, however, generally not significant in the panel estimations. Also the impact of two bilateral

\footnotetext{
${ }^{12}$ Note that the population variables in a gravity equation influence the coefficients on the GDP variables and should be interpreted together (see Frankel and Wei 1997c: pages 57-59). For instance, the home-nation GDP elasticity of 0.81 and the home-nation population elasticity of 0.37 in Regression 1 (Table 3) can be interpreted as home-nation GDP elasticity of 1.18 along with a home-nation GDP per capita elasticity of -0.37 . The two specifications (one with GDP and GDP per capita, the other with GDP and population) are mathematically equivalent due to the use of logs.

${ }^{13}$ To be precise, Frankel and Wei (1997b) use the log of GDP per capita - not population variables - in their OLS regressions. Consequently, a positive coefficient on the GDP per capita variable is equivalent to a negative coefficient of the same magnitude on the population variable.
} 
trade-cost measures - geographic distance and FTAs — are in line with recent trade literature findings (e.g. Baier and Bergstrand 2007). First, the elasticity of exports with respect to distance ranges between -1.20 and -1.33 . Second, FTAs are estimated to increase exports by $15 \%$ to $61 \%$ depending on the specification (only in Table 4's Regression 5 and 6 is the FTA coefficient not significant).

Before turning to the interpretations of our variables of principal interest - the trade effects of ISO 9000 penetration - we test for the endogeneity of international standardization. Recall that we have argued that endogeneity is a crucial analytical issue that has often been neglected in previous trade studies. We can formally test for the presence of endogeneity by comparing the coefficient estimates from Table 3 (where the ISO variables act as their own instruments) with the coefficient estimates from Table 4 (where ISO 14000 adoption levels are used as instrumental variables for the ISO 9000 variables). ${ }^{14}$ Significant differences in the coefficient estimates between Table 3 and 4 are discernable, and Hausman specification tests reject [at the $1 \%$ confidence level for Regressions 1, 2, 3, 5 and 6 and at the $10 \%$ confidence level for Regression 4] the null hypothesis regarding the difference in coefficient estimates being nonsystematic. Accordingly, Hausman tests confirm our prior that endogeneity matters empirically in the context of international standards and international trade.

In line with the presence of endogeneity, a visual comparison of Table 3 and 4 for the results concerning the three ISO variables indicates some significant differences concerning the

\footnotetext{
${ }^{14}$ The instrumental variables include home-nation adoption of ISO 14000, host-nation adoption of ISO 14000 and the interaction of the two. F-tests support the strength of ISO 14000 adoptions as instrumental variables at the 1\% confidence level for all three ISO 9000 variables in all six regressions (see Table A1 in the Appendix). Note that we use the same set of first-stage regressions for the pooled OLS, the FE and the FD specifications, since the inclusion of fixed effects (or first-differencing) in the first stage significantly lowers the strength of our instruments based on ISO 14000 adoptions.
} 
impact of ISO 9000 diffusion on trade. First, the results in Table 3 suggest a robustly significant positive impact for home-nation ISO 9000 on exports. Further, this positive push regarding home-nation ISO diffusion holds in Table 4 when we more completely account for endogeneity in ISO 9000 adoption. Second, the Table 3 results indicate that host-nation ISO 9000 diffusion yields some positive impact on exports (i.e., significant 'pull' effects are present in Regressions 1 and 4), while the Table 4 results - where endogeneity is more fully accounted for - indicate a negative or insignificant 'pull' on exports. Thus, the compliance-cost effect embedded in hostnation ISO 9000 diffusion becomes stronger/more-evident once the endogeneity of international standardization is taken into account. This result accords with the intuition that ISO 9000 diffusion is primarily driven by the trade orientation of an economy - e.g., trade oriented nations tend to adopt ISO 9000 in order to conform to foreign buyer requirements or source more efficiently from foreign suppliers. Third, the interaction of home-nation and host-nation standardization is more robust in the IV regressions (Table 4) as compared to the non-IV regressions (Table 3); though, it is important to underscore that this interaction effect is positive when both employing and not employing the IV techniques-i.e., the common-language effect is a relatively robust channel via which standardization impacts international trade. ${ }^{15}$

We also test for a specific form of heteroscedasticity in the error term by using a Parktype regression (Park 1966; Santos Silva and Tenreyro 2006): where a test-coefficient value different than 2 suggests that log-linearization of the gravity equation leads to endogeneity bias. Each regression in Tables 3 and 4 reports the result for this test of heteroscedasticity. When considering these results as a whole, it is first apparent that the panel regressions involve less heteroscedasticity (since the test coefficient is closer to 2 in the panel estimations) as compared to

\footnotetext{
${ }^{15}$ The common-language result is also robust to including home- and host-nation-specific time dummies as suggested by (Anderson and van Wincoop 2003) and Feenstra (2004). The full results of these regressions are available upon request.
} 
the pooled OLS regressions. Yet more importantly, only the first-differenced specifications (Regressions 3 and 6) indicate a lack of heteroscedasticity (i.e., test coefficients that are not statistically different from 2). Accordingly, the log-linearization that is commonly employed in gravity equation analysis is generally less problematic in our panel specifications, but is even more immune to this type of endogeneity bias in our FD specifications.

In short, ISO 9000 diffusion appears to be subject to some endogeneity bias - a bias which needs to be accounted for in order to understand the relationship between international standardization and international trade. Accordingly, Regression 6 in Table 4 (first-differencing with multilateral resistance terms and instrumentation) represents our preferred regression specification, as it most fully addresses the various endogeneity concerns raised in the literature. This particular specification involves instrumental variable techniques in order to generally deal with endogeneity concerns, multilateral resistance terms to control for biases induced by general equilibrium effects, and a first-differencing. The first-differencing is important because the heteroscedasticity tests reported at the bottom of Tables 3 and 4 suggest that only the FD specifications do not suffer from the endogeneity bias caused by log-linearization of the gravity equation. Accordingly, the remaining interpretations of our findings are based on this preferred specification due to the fact that it deals with endogeneity via multiple means.

First, we find strong support for the common-language effect, as high levels of ISO 9000 adoption in both the home and host nation spur increased country-pair trade. While the ability of standards to reduce communication frictions between trading partners has been appreciated by many scholars (e.g., Casper and Hancké 1999; Bénézech et al. 2001; Blind 2001), it has been difficult to empirically pin down these effects. Accordingly, common-language effects previously manifested via the home and host standardization measures. Capturing the common-language 
effect via the interaction of home and host ISO helps then disentangle these effects and suggests that the common-language effect is a robust channel via which standardization increases trade.

Second, we find support for the enhanced-competitiveness effect captured by home-nation standardization. This result is consistent with the literature (e.g., Swann, Temple and Shurmer 1996; Blind 2001, 2004; Ganslandt and Markusen 2001) that finds home-nation standardization to enhance the competitiveness of exports. Thus, the positive push for home-nation standardization found in previous work is supported when we more fully control for simultaneity between exports and standardization.

Third, the positive (though insignificant) coefficient estimate for host-nation standardization appears to indicate that negative compliance-cost effect - which is embedded in host-nation standardization -seems to be relatively insignificant as compared to the positive information effect. Still, this does not completely undermine the validity of the concerns by Maskus, Wilson and Otsuki (2000) and others regarding the ability of international standards to hinder trade between nations. According to our results, the trade-hindering elements can off-set and even outweigh - the trade-fostering elements of host-nation standardization when homenation ISO diffusion levels are significantly negative. ${ }^{16}$ As previously noted, international standards have been generally found to promote trade more than national standards (Barrett and Yang 2001; Blind 2001; Moenius 2004; Czubala, Shepherd and Wilson 2007; Shepherd 2007); and moreover, ISO 9000 has generally been considered to be the standard least subject to protectionist rationales (Blind 2004; Moenius 2006). Accordingly, if we are able to detect trade dampening effects due to the adoption of ISO 9000, then it stands to reason that many other standards - if not all - will also involve some trade-hindering elements. The next section looks

\footnotetext{
${ }^{16}$ Note that our explanatory variables are in logs; hence, ISO adoption - which we measure relative to population size - can take negative values.
} 
deeper into this question by examining the partial and total effects of ISO 9000 diffusion on individual country-pair trade flows.

\section{Fortress Europe: ISO 9000 as a Device to Form an EU Standardization Union?}

The empirical results highlight the fact that the worldwide diffusion of ISO 9000 potentially involves some trade-hindering elements; in particular, ISO 9000 adoption in hostnations can lead to the curtailment of imports from other nations. In light of the potential presence of this trade-dampening effect, the obvious next question is which nations might experience reduced exports due to the adoption of ISO standards in a host-nation environment? Akin to the concerns addressed by Frankel and Wei (1997a) regarding the European integration process being used to create a 'Fortress Europe', Hanson (2005) notes that the worldwide diffusion of standards has been considered by some as a means by the EU to protect domestic competitors and reduce imports. ${ }^{17}$ Gandal and Shy (2001) show that when conversion costs are relatively high and network effects are relatively minimal, then nations can increase welfare by creating a standardization union for the purpose of increasing trade for member countries at the expense of decreased trade from non-member countries. Two additional points highlight the potential for ISO 9000 to be employed by European nations as a barrier to market entry and a tariff on international trade.

First, ISO 9000 has been used in Europe as a standard against which to assess performance in government procurements and in setting minimum quality requirements for products that affect public safety. In particular, the 1992 Single Market Initiative initiated by the then European Community involved a significant public safety argument obliging firms to attain

\footnotetext{
${ }^{17}$ It is healthy to point out that Frankel and Wei (1997a) generally find - like most other studies - the EU integration process to be trade enhancing with respect to imports from non-EU nations (i.e., little trade-diversion takes place).
} 
a uniquely designed CE Mark in order to gain access to certain European markets. ${ }^{18}$ Furthermore, the majority of the conformity assessment modules necessary for the CE marking program were based on the ISO 9000 series; i.e., the ISO 9000 quality control systems were the foundation for the CE mark—-see Hanson (2005) for more details. Thus, ISO 9000 certified firms find it easier to obtain the $\mathrm{CE}$ mark and, as a consequence, to access the European market; though, the $\mathrm{CE}$ mark does not make it easier to obtain ISO certification.

Second, it bears pointing out that the effort toward worldwide diffusion of international standards has been led by the EU and confirmed by the expansion of international institutions like the International Organization for Standardization (Casella 1996). Hanson (2005) points out that the EU has been far more unified in its participation in the International Organization for Standardization than have other nations: for instance, the EU embraces the International Organization for Standardization, receives one vote for every nation, and has strong representation (usually chairing) in the technical committees where the standards are designed and set; while the US is more interested in reciprocal recognition of national standards, receives only one vote as it is one nation, and often finds its comments ignored in the standard-setting process. It is no surprise then that standards developed by this process are considered by many to serve European interests (Hanson 2005).

Furthermore, quite a bit of policy-oriented literature exists concerning the impact of standard-counts and technical-regulations on intra-EU and extra-EU trade-flows-results which often conform to standardization-union properties by suggesting that EU standardization leads to intra-EU trade-creation and trade-diversion for EU imports from non-EU nations. In terms of standardization enhancing intra-EU trade: Brenton, Sheehy and Vancauteren (2001) find a substantial increase for Polish and Hungarian exports to EU-15 nations in industries where

\footnotetext{
${ }^{18}$ Depending on the product category, the EC Mark had to be attained by some time between 1992 and 1995.
} 
standards applied; and Vancauteren and Weiserbs (2005) support increased intra-EU trade from 1990 to 1998 due to European technical regulation harmonization. In terms of EU standardization decreasing EU imports from non-EU nations: Moenius (2006) finds EU importer standards to decrease agricultural imports from non-EU nations; Czubala, Sheperd and Wilson (2007) find that both the counts of ISO-harmonized and non-ISO-harmonized standards reduce EU imports from African nations, though ISO-harmonized standard counts are less trade restrictive; and Spencer Henson et al. (2000) found developing nations very constrained in their ability to export food to developed nations with standards being the highest barrier to enter the EU. Furthermore, Gasiorek, Smith and Venables (1992) and Michalek et al. (2005) both found EU standardization to increase trade between EU members but impede imports from outside the EU.

In order to get a more complete picture of when additional home-nation and host-nation ISO 9000 adoptions enhance or hinder trade, Figures 1 and 2 use the coefficient estimates for the three ISO variables from Regression 6 in Table 4 to illustrate the partial and total effects on exports of additional ISO 9000 diffusion. ${ }^{19}$ Figure 1 shows the elasticity of exports with respect to home-nation adoptions at different levels of host-nation adoption. Figure 2 shows the elasticity of exports with respect to host-nation adoptions at different levels of home-nation adoption. While these partial effects are simple linear functions of ISO 9000 diffusion in the respective host or home nation, the total effects depend on additional country-pair-year factors-see the appendix for explanation of these factors. ${ }^{20}$ Thus, the total effects are illustrated by a cloud of circles in both figures - with each circle representing one country-pair in a given year. Notice that

\footnotetext{
${ }^{19}$ The maximum and minimum levels of ISO 9000 on the horizontal axis in Figures $1 \& 2$ are chosen to reflect the sample's distribution. Note that the log values of ISO 9000 adoption are negative when the number of certificates is less than 1 per million inhabitants in a given country.

${ }^{20}$ The estimation results from Regression 6 also allow differentiating between the partial and total effects for the distance and FTA variables due to the inclusion of theoretically-motivated multilateral resistance terms (Baier and Bergstrand 2009). However, we do not do so as these constructs do not constitute our main focus here.
} 
the marginal impact of additional home-nation ISO 9000 diffusion (Figure 1) is positive and for the most part significant; i.e., the impact of additional home standardization is positive for almost all the relevant levels of host-nation adoption in our sample. Further, this positive home-nation effect—both the partial and the total effect—-becomes larger at higher levels of host-nation ISO adoption. $^{21}$

When we consult Figure 2, however, the marginal impact of additional host-nation ISO 9000 adoption only becomes positive once home-nation diffusion levels are sufficiently large. Namely, the point estimate for the partial effect turns positive at 0.31 certifications per million inhabitants $(\log (0.31)=-1.16)$ - a fairly low threshold. Given the distribution of ISO penetration levels in our sample for 2005 (Table 1), host-nation diffusion pulls-in trade from all nations (i.e., all nations benefit from worldwide diffusion of ISO standards), but pulls-in greater levels of trade from ISO-rich nations. That said, some nations had ISO penetration levels in 1995 and 2000 that were below this threshold, thus diffusion of ISO 9000 in their trading-partner nations represented a threat to their exports at that time. Furthermore, when one considers the total effect (i.e., adjusting for general equilibrium effects), many country-pair types exist where trade is actually hindered by host-nation certification: the multiple circles lying in the negative elasticity region of Figure 2 give evidence to this result. Thus by allowing the common language effect of ISO 9000 to manifest in general equilibrium, we elicit results suggesting that host-nation certification can hinder trade from exporter nations that have not significantly adopted ISO 9000; i.e., compliancecost effects dominate information effects when home-nation ISO levels fall below a critical threshold. This trade-hindering result is statistically significant, as indicated by the $90 \%$ confidence interval in Figure 2.

\footnotetext{
${ }^{21}$ To be precise, there are a few country-pair-year observations where the total effect is negative and statistically significant.
} 
Table 5 illustrates which nations generally benefit and which generally suffer when ISO 9000 diffusion increases in the relevant trading-partner nations. Namely, the table presents average export elasticities (for both home and host ISO diffusion) based on total effects for all nations in the sample. The ordering of the nations in the table is by descending export elasticities for host-nation ISO diffusion in order to clearly distinguish which nations generally gain exports and which generally lose exports when ISO becomes more widespread throughout the world. Before turning to analyzing the impact of host-nation diffusion on the exports of various nations, it is important to first note that the results for home-nation adoption are generally robust and consistent across all nations; i.e., the exports of all nations tend to uniformly benefit from homenation diffusion of ISO 9000 with the average elasticity of exports very close to 0.06 for almost all nations. The US represents a notable exception in that it has an elasticity equal to 0.146 , thus the US tends to elicit relatively large increases in exports when it adopts ISO standards.

When it comes, however, to the impact of host-nation ISO 9000 diffusion on exports, then there exists wide variation across the different nations in our sample. For instance, Table 5 illustrates that for roughly half of the nations in our sample the average elasticity of exports with respect to host-nation diffusion is negative. ${ }^{22}$ In other words, these nations generally find their exports to decrease on average when the host-nations they trade with adopt ISO 9000. Moreover, the nations experiencing negative export elasticities for host-nation ISO diffusion tend to be either developing or transition nations. While some developing and transition nations do elicit a positive pull to their exports when ISO 9000 is adopted in their trading-partner host-nations, it is important to point out that this positive pull tends to be much lower than the positive pull experienced by developed nations: which tend to have the largest average export elasticities for

\footnotetext{
${ }^{22}$ The number of nations below the threshold decreases with time, as worldwide certification levels increase.
} 
host-nation ISO diffusion. ${ }^{23}$ In other words, developed nations generally find their exports to increase the most when the host-nations they trade with adopt ISO 9000. In short, the export gains of developing nations are not as large as the export gains of developed nations when ISO 9000 reaches higher levels of worldwide diffusion. These results are in line with the concerns by many scholars (e.g., Maskus, Wilson and Otsuki 2000; Blind 2001; Czubala, Shepherd and Wilson 2007) that firms from developing nations may be harmed by standardization, as they have no influence over the standardization process and find the compliance costs to be substantially high.

The second point to note is that the nations which benefit the most from worldwide diffusion of ISO 9000 tend to be European. For instance, among the thirty nations (roughly one third of our sample) experiencing host-nation export-elasticities above 0.050 on average, twentytwo are European and twenty are EU members. Furthermore, only eight non-European nations (Singapore, Israel, Australia, New Zealand, Hong Kong, Japan, Canada, and Korea) have adopted ISO 9000 at sufficiently high levels to equivalently gain from worldwide diffusion of standardization. In other words, only eight non-European nations have essentially joined the 'ISO' club. Moreover, the US (at 150 certificates per million inhabitants and an average hostnation diffusion elascticity of 0.040 ) fares only moderately well. Hence, increased ISO 9000 standardization in trading-partner nations tends, in general, to increase US exports to these nations, but the exports of European nations experience a larger increase. These results are in line with the idea that the worldwide diffusion of ISO 9000 standards sponsored by the International Organization for Standardization principally benefited European nations and gives some support

\footnotetext{
${ }^{23}$ South Africa represents a lone exception as it has the highest host-nation elasticity of 0.027 , thus South Africa has substantially gained from the worldwide diffusion of ISO 9000.
} 
to US-based critics who claimed that ISO 9000 certification represented a specific threat to many export interests (Hanson 2005).

In order to provide a more intuitive grasp on the economic significance of our findings (based on the total effects from Table 4's Regression 6), we can take some representative nations (UK, Australia, US, Mexico and Guatemala) and consider what potentially happens to trade between these nations due to an increase in their 2005 ISO adoption levels. For instance, when Australia increases ISO 9000 adoptions by 10\%, Australia's exports to the UK, the US, Mexico and Guatemala respectively change by $1.6 \%, 1.0 \%, 0.4 \%$ and $-0.6 \%$. These simulations illustrate the above point regarding the impact of additional home-nation adoptions almost always being positive regardless of the different host-nation adoption levels. However, when we consider the impact on exports to Australia from the UK, the US, Mexico and Guatemala due to that same $10 \%$ increase in Australia's standardization, then trade flows respectively change by $1.0 \%, 0.4 \%$, $-0.3 \%$ and $-1.2 \%$. These simulations illustrate a few of the above points concerning the impact of worldwide diffusion of standardization: members of the 'standardization union' (e.g., the UK) gain the most from the standardization process; nations falling just outside of the club (e.g., the US) do not gain as much as club members; and many developing and transition nations (e.g., Mexico and Guatemala) tend to experience export losses.

Finally, our results allow formulating some conclusions regarding the effects of ISO 9000 diffusion on global trade as a whole. Table 6 presents summary statistics for the ISO export elasticities across all the country-pairs in our sample. It is clear that diffusion of ISO 9000 in both home-nations and host-nations leads to increased trade on average; i.e., total effects are generally positive. Thus while there are winners and losers from the worldwide diffusion of ISO 9000, global trade as a whole seems to benefit from the spread of the ISO 9000 standard. 
In sum, our findings suggest that the proliferation of ISO 9000 spurs global trade. Yet, it is the trade between ISO-rich nations which is enhanced the most by ISO 9000, while other types of trade-flows can actually be hampered by worldwide diffusion of ISO standards. It is the nations with the lowest levels of ISO penetration which find ISO 9000 diffusion in the rest of the world to be a de facto barrier to their exports. In terms of evaluating the 'fortress Europe' hypothesis, our results indicate that European nations (the supposed 'standardization union' members) are among the nations which benefit the most from worldwide diffusion of ISO 9000 . The US and a number of developing and transition nations also tend to generally benefit from ISO 9000 adoptions, though to a lesser extent than the twenty-three European nations and the eight additional nations which essentially form the ISO club. Indeed, increased adoption within the standardization union strengthens intra-union trade, enhances union exports to the outside world, and protects the union from imports from most of the developing and transition nationswhich lag behind in terms of ISO adoptions. Accordingly, the above results illustrate that international standards can become de facto trade barriers for some nations even though they are not necessarily de jure trade barriers and do in fact increase global trade as a whole.

\section{Conclusion}

Motivated by the need to better understand the implications of worldwide diffusion of standardization on trade, this paper empirically assesses the link between international standards and international trade. Empirical scholarship on the standards/trade relationship has been held up by three particular methodological challenges: measurement problems, varied effects, and endogeneity concerns. By investigating the impact of ISO 9000 - by far the most widely implanted international standard - on trade between 91 nations from 1995 to 2005, we are able to surmount some of these methodological challenges that have encumbered previous scholarship. 
First, we consider the penetration of ISO 9000 in a specific national environment, thus employing a continuous standardization measure as opposed to the commonly-used inventory approach to capture standardization. Second, we allow ISO 9000 to manifest via multiple channels: an enhanced-competitiveness effect captured by home-nation standardization; a combined information/compliance-cost effect captured by host-nation standardization; and a commonlanguage effect captured by the interaction of home and host standardization. Third, we employ panel data techniques (first-differencing and fixed-effects), multilateral resistance terms (a la Baier and Bergstrand 2009), and instrumental variable (IV) techniques in order to control for ISO 9000's potential endogeneity.

The empirical results from our gravity trade equations yield three main findings concerning the standards/trade relationship. First, we find strong support for the commonlanguage aspect of ISO 9000, as combining high certification levels in both home and host nations robustly promotes trade. In other words, the positive effects of additional adoptions in one nation are enhanced by higher ISO 9000 levels in the corresponding partner nation from a country-pair. Thus, ISO 9000 appears to lower information asymmetries between firms hailing from different nations and allows more efficient organization of vertical relations in a bilateral trade relationship. Second, the enhanced-competitiveness effect captured by home-nation standardization also finds strong support. This finding corroborates the previous literature on the standards/trade relationship which generally found the quality-signaling elements of standardization to involve a robust positive push with respect to home-nation exports. Yet unlike this study, the previous literature did not comprehensively tackle endogeneity. Third, we find the compliance-cost effect - which is embedded along with an information effect in host-nation standardization - to be relatively strong in the estimations employing instrumental variable techniques. This result provides some backing to the concerns of many scholars' that host-nation 
standardization can increase adaptation costs for home exporter firms and reduce exports to a particular host-nation.

The natural next question concerns which types of nations tend to benefit and which tend to lose from the worldwide diffusion of ISO 9000 standardization. When we compare the empirical results with actual ISO 9000 adoption levels, we find some support for a "Fortress Europe". First, the exports of European nations increase the most when other nations adopt ISO 9000, while the US benefits a bit less from worldwide diffusion of standardization. Furthermore, all of the nations which find exports to decrease when host-nations adopt ISO 9000 are developing or transition nations. Thus, these nations find the trade-dampening compliance-cost effects to outweigh the trade-promoting information effects when it comes to host-nation standardization. Since the European nations have the highest levels of ISO penetration, it is exports to European nations from nations with low adoption levels that are most threatened by standardization. This result is consistent with the concerns by Maskus, Wilson and Otsuki (2000), Shepherd (2007) and others regarding firms in developing nations lacking the necessary information, technology, managerial capacity and finances to adopt production processes quickly in order to meet developed-world standards. Thus, the "Fortress Europe" hypothesis finds some empirical support here, as the worldwide diffusion of ISO 9000 appears to involve some characteristics consistent with the fundamentals - enhanced intra-union trade and union exports at the expense of imports from outside the union - of a standardization union.

In sum, the empirical results strongly support the common language aspects of ISO 9000, the robustness of the enhanced-competitiveness effect due to home-nation standardization, and also exhibit evidence that ISO 9000 involves trade-hindering elements via host-nation adoption raising the compliance costs of exporters from other nations. In particular, diffusion of ISO 9000 represents a de facto trade barrier for the developing and transition nations that lag behind in 
terms of adoption, whereas ISO-rich nations (mostly European) reap the majority of the benefits from worldwide standardization. It bears stating that ISO 9000 is the quintessential international standard: by far the most successful implantation of any international standard, and generally considered to be the standard least subject to trade-dampening effects. Therefore, if we find ISO 9000 - the most international of standards - to have protectionist elements, then virtually all standards in existence will seemingly involve some trade-hindering effects. Thus, our findings are in line with the observation by Maskus, Wilson and Otsuki (2000: 6) that no standards analogue exists to the claim that free trade in goods is globally optimal. 


\section{References}

Anderson, Shannon W., J. Daniel Daly, and Marilyn F. Johnson, (1995). “The Value of Management Control Systems: Evidence on the Market Reaction to ISO 9000 Quality Assurance Certificates,” University of Michigan Business School Working Paper 9501-16.

Anderson, Shannon W., J. Daniel Daly, and Marilyn F. Johnson, (1999). "Why Firms seek ISO 9000 Certification: Regulatory Compliance or Competitive Advantage?” Production and Operations Management, vol. 8, pp. 28-43.

Anderson, James E., (1979). “A Theoretical Foundation for the Gravity Equation,” American Economic Review, vol. 69, pp. 106-116.

Anderson, James E, and Douglas Marcouiller, (2002). "Insecurity and the Pattern of Trade: An empirical Investigation," Review of Economics and Statistics, vol. 84, pp. 342-252.

Anderson, James E., and Eric van Wincoop, (2003). "Gravity with Gravitas: A Solution to the Border Puzzle," American Economic Review, vol. 93, pp. 170-192.

Baier, Scott L., and Jeffrey H. Bergstrand, (2002). "On the Endogeneity of International Trade Flows and Free Trade Agreements," mimeo.

Baier, Scott L., and Jeffrey H. Bergstrand, (2007). "Do Free Trade Agreements Actually Increase Members' International Trade?” Journal of International Economics, vol. 71, pp. 72-95.

Baier, Scott L., and Jeffrey H. Bergstrand, (2009). "Bonus vetus OLS: A simple method for approximating international trade-cost effects using the gravity equation," Journal of International Economics, vol. 77, pp. 77-85.

Baldwin, Richard, (2000). "Regulatory Protectionism, Developing Nations and a Two-tier World Trade System,” CEPR Discussion Paper 2574.

Barrett, Christopher B., and Yi-Nung Yang, (2001). "Rational incompatibility with international product standards," Journal of International Economics, vol. 54, pp. 171-191. 
Bénézech, Danièle, Gilles Lambert, Blandine Lanoux, Christophe Lerch, and Jocelyne LoosBaroin, (2001). "Completion of knowledge codification: an illustration through the ISO 9000 standards implementation process," Research Policy, vol. 30, pp. 1395-1407.

Bergstrand, Jeffrey H., (1985). "The Gravity Equation in International Trade: Some Microeconomic Foundations and Empirical Evidence," Review of Economics and Statistics, vol. 67, pp. $474-481$.

Blind, Knut, (2001). “The Impact of Innovations and Standards on Trade of Measurement and Testing Products: Empirical Results of Switzerland's Bilateral Trade Flows with Germany, France and the UK," Information Economics and Policy, vol. 13, pp. 439-460.

Blind, Knut, (2002). "Driving Forces for Standardization at Development Organizations," Applied Economics, vol. 34, pp. 1985-1998.

Blind, Knut, (2004). The Economics of Standards: Theory, Evidence, Policy, Northampton, MA: Edward Elgar.

Boom, Anette, (1995). “Asymmetric International Minimum Quality Standards and Vertical Differentiation,” Journal of Industrial Economics, vol. 43, pp. 101-119.

Brenton, Paul, John Sheehy, and Marc Vancauteren, (2001). "Technical Barriers to Trade in the European Union: Importance for Accession Countries," Journal of Common Market Studies, vol. 39 , pp. $265-284$.

Casella, Alessandra, (1996). "Free Trade and Evolving Standards," in (Bhagwati Jagdish and Robert Hudec, eds.), Fair Trade and Harmonization: Prerequisites for Free Trade?, Vol. 1, pp. 119-156, Cambridge, MA: MIT Press.

Carrère, Cèline, (2006). "Revisiting the Effects of Regional Trade Agreements on Trade Flows with Proper Specification of the Gravity Model," European Economic Review, vol. 50, pp. 223-247.

Casper, Steve, and Bob Hancké, (1999). “Global Quality Norms with National Production Regimes: ISO 9000 Standards in the French and German Car Industries," Organization Studies, vol. 20, pp. 961-985. 
Clougherty, Joseph A., and Michal Grajek, (2008). "The Impact of ISO 9000 Diffusion on Trade and FDI: A New Institutional Analysis," Journal of International Business Studies, vol. 39, pp. 613-633.

Corbett, Charles J. and David A. Kirsch, (2001). "International Diffusion of ISO 14000 Certification," Production and Operations Management, vol. 10, pp. 327-342.

Czubala, Witold, Ben Shepherd, and John S. Wilson, (2007). "Help or Hindrance?: The Impact of Harmonized Standards on African Exports," World Bank - Policy Research Working Paper 4400 .

Deardorff, Alan V., (1998). "Determinants of Bilateral Trade: Does Gravity Work in a Neoclassical World?" in (Jeffrey A. Frankel, ed.), The regionalization of the world economy, pp. 7-32, Chicago, IL: University of Chicago Press.

Deardorff, Alan V., and Robert M. Stern, (1998). Measurement of Nontariff Barriers, Ann Arbor: University of Michigan Press.

Delmas, Magali A., (2002). "The diffusion of environmental management standards in Europe and in the United States," Policy Sciences, vol. 35, pp. 91-119.

Dissanayaka, Sunil M., Mohan M. Kumarsawamy, Khalid Karim, and Marton Marosszeky, (2001). "Evaluating Outcomes from ISO 9000-certified Quality Systems of Hong Kong Constructors," Total Quality Management, vol. 12, pp. 29-40.

Eaton, Jonathan, and Samuel Kortum, (2002). "Technology, Geography, and Trade," Econometrica, vol. 70, pp. 1741-1779.

Feenstra, Robert, (2004). Advanced International Trade: Theory and Evidence, Princeton, NJ: Princeton University Press.

Frankel, Jeffrey A., and Shang-Jin Wei, (1997a) "Estimated Effects of Trading Blocs," in (Frankel, Jeffrey A., ed.), Regional Trading Blocks in the World Economic System, pp. 77113, Washington, DC: Institute for International Economics. 
Frankel, Jeffrey A., and Shang-Jin Wei, (1997b). "Extensions of the Empirical Analysis," in (Frankel, Jeffrey A., ed.), Regional Trading Blocks in the World Economic System, pp. 115148, Washington, DC: Institute for International Economics.

Frankel, Jeffrey A., and Shang-Jin Wei, (1997c). “The Gravity Model of Bilateral Trade,” in (Frankel, Jeffrey A., ed.), Regional Trading Blocks in the World Economic System, pp. 49-76, Washington, DC: Institute for International Economics.

Freund, Caroline L., and Diana Weinhold, (2004). "The effect of the Internet on international trade," Journal of International Economics, vol. 62, pp. 171-189.

Gandal, Neil, and Oz Shy, (2001). "Standardization policy and international trade," Journal of International Economics, vol. 53, pp. 363-383.

Ganslandt, Mattias, and James R. Markusen, (2001). "National Standards and International Trade,” Research Institute of Industrial Economics Working Paper 547.

Gasiorek, Michael, Alasdair Smith and Anthony J. Venables, (1992). “1992: Trade and Welfare A General Equilibrium Model” in (L.A. Winters, ed.), Trade Flows and Trade Policy after 1992, pp. 35-62, Cambridge, MA: Cambridge University Press.

Guler, Isin, Guillén, Mauro, F. and Macpherson, John Muir, (2002). “Global Competition, Institutions, and the Diffusion of ISO 9000 Quality Certificates," Administrative Science Quarterly, vol. 47, pp. 207-232.

Hanson, David, (2005). CE Marking, Product Standards and World Trade, Northampton, MA: Edward Elgar.

Harrigan, James, (1993). “OECD Imports and Trade Barriers in 1983,” Journal of International Economics, vol. 35, pp. 91-111.

Helpman, Elhanan, and Paul Krugman, (1985). Market Structure and Foreign Trade, Cambridge, MA: MIT Press. 
Henson, Spencer, Rupert Loader, Alan Swinbank, Maury Bredahl, and Nicole Lux, (2000). "Impact of Sanitary and Phytosanitary Measures on Developing Countries," Reading, UK: Center for Food Economics Research.

Hudson, John, and Philip Jones, (2003). “International Trade in 'Quality Goods': Signalling Problems for Developing Countries,” Journal of International Development, vol. 15, pp. 9991013.

Hummels, David, and James Levinsohn, (1995). "Monopolistic Competition and International Trade: Reconsidering the Evidence," Quarterly Journal of Economics, vol. 110, pp. 799-836.

ISO, The ISO Survey of ISO 9000 and ISO 14000 Certificates, Eleventh cycle - 2001, (2002). Geneva: ISO Central Secretariat.

ISO, (2005). ISO/TC 176 Business Plan N847, mimeo.

ISO, The ISO Survey - 2005, (2006). Geneva: ISO Central Secretariat.

Laird, Sam, and Alexander Yeats, (1990). Quantitative Methods for Trade-Barrier Analysis, New York, NY: New York University Press.

Lee, Jong-Wha, and Phillip Swagel, (1997). “Trade barriers and trade flows across countries and industries," Review of Economics and Statistics, vol. 79, pp. 372-382.

Linnemann, Hans, (1966). An Econometric Study of International Trade Flows, Amsterdam: North-Holland.

Magee, Chris, (2003). "Endogenous Preferential Trade Agreements: An Empirical Analysis," Contributions to Economic Analysis and Policy, vol. 2(1), article 15.

Maskus, Keith E., John S. Wilson, and Tsunehiro Otsuki, (2000). “Quantifying the Impact of Technical Barriers to Trade: A Framework for Analysis," World Bank Policy Research Working Paper 2512.

Maskus, Keith E., Tsunehiro Otsuki, and John S. Wilson, (2004). "The Costs of Complying with Foreign Product Standards for Firms in Developing Countries: An Econometric Study," Institute of Behavioral Science Working Paper 2004-0004. 
Matutes, Carmen, and Pierre Regibeau, (1996). "A Selective Review of the Economics of Standardization, Entry Deterrence, Technological Progress and International Competition," European Journal of Political Economy, vol. 12, pp. 183-209.

Michalek, Jan, Jan Hagemejer, Victoria Roshal, Jacek Rothert, Alfred Tovias, Agnieszka Pugacewicz, and Mark Vancauteren, (2005). "Comparative analysis of importance of technicial barriers to trade (TBT) for Central and Eastern European Countries and Mediterranean Partner Countries exports to the EU," FEMISE Research Programme FEMISE Research No. 22-03.

Moenius, Johannes, (2004). "Information versus Product Adaptation: The Role of Standards in Trade," mimeo. Northwestern University.

Moenius, Johannes, (2006). "International Standardization as a Strategic Tool: Do National Standards Hinder or Promote Trade in Electrical Products," mimeo IEC - Geneva, Switzerland.

Park, R. E., (1966). "Estimation with Heteroscedastic Error Terms," Econometrica, vol. 34, pp. 888.

Prakash, Aseem, and Matthew Potoski, (2006). "Racing to the Bottom? Trade, Environmental Governance, and ISO 14001," American Journal of Political Science, vol. 50, pp. 350-364.

Prakash, Aseem, and Matthew Potoski, (2007). "Investing Up: FDI and the Cross-Country Diffusion of ISO 14001 Management Systems," International Studies Quarterly, vol. 51, pp. 723-744.

Preeg, Ernest H., (1998). From Here to Free Trade, Chicago, IL: University of Chicago Press.

Rauch, James E., (1999). "Networks versus markets in international trade," Journal of International Economics, vol. 48, pp. 7-35.

Rauch, James E., and Victor Trindade, (2002). "Ethnic Chinese Networks in International Trade," Review of Economics and Statistics, vol. 84, pp. 116-130. 
Rose, Andrew X., (2004). “Do We Really Know That the WTO Increases Trade?” The American Economic Review, vol. 94, pp. 98-114.

Shepherd, Ben, (2007). "Product Standards, Harmonization, and Trade: Evidence from the Extensive Margin,” World Bank Policy Research Working Paper 4390.

Santos Silva, J.M.C., and Silvana Tenreyro, (2006). “The Log of Gravity,” The Review of Economics and Statistics, vol. 88, pp. 641-658.

Swann, Peter, Paul Temple, and Mark Shurmer, (1996). "Standards and Trade Performance: The UK Experience,” Economic Journal, vol. 106, pp. 1297-1313.

Terlaak, Ann, and Andrew A. King, (2006). "The effect of certification with the ISO 9000 quality management standard: A signaling approach," Journal of Economic Behavior and Organization, vol. 60, pp. 579-602.

Terziovski, Milé, Damien Power, and Amrik S. Sohal, (2003). “The longitudinal effects of the ISO 9000 certification process on business performance," Production, Manufacturing and Logistics, vol. 146, pp. 580-595.

Tinbergen, Jan, (1962). Shaping the World Economy, New York: The Twentieth Century Fund.

Trefler, Daniel, (1993). "Trade liberalization and the theory of endogenous protection: an econometric study of U.S. import policy," Journal of Political Economy, vol. 101, pp. 138160.

Vancauteren, Marc, and Daniel Weiserbs, (2005). "Intra-European trade of Manufacturing Goods: an Extension of the Gravity Model," Université Catholique de Louvain - Discussion Paper 26.

Vastag, Gyula, (2004). 'Revisiting ISO 14000 Diffusion: A New 'Look' at the Drivers of Certification," Production and Operations Management, vol. 13, pp. 260-267.

Wooldridge Jeffrey M., (2002). Econometric Analysis of Cross Section and Panel Data, Cambridge and London: the MIT Press. 
Table 1

List of countries in our sample and number of ISO 9000 certifications

\begin{tabular}{|c|c|c|c|c|c|}
\hline \multirow{2}{*}{ Country/Region } & \multicolumn{2}{|c|}{ ISO 9000 certifications } & \multirow{2}{*}{ Country/Region } & \multicolumn{2}{|c|}{ ISO 9000 certifications } \\
\hline & per mln inhab. & count & & per mln inhab. & count \\
\hline Italy & 1672.65 & 98028 & Denmark & 225.26 & 1219 \\
\hline Switzerland & 1669.20 & 12413 & Malaysia & 222.04 & 5695 \\
\hline Hungary & 1533.15 & 15464 & Lithuania & 173.39 & 591 \\
\hline Singapore & 1447.10 & 6282 & Mauritius & 163.28 & 202 \\
\hline Czech Republic & 1245.25 & 12743 & Turkey & 151.67 & 10929 \\
\hline Israel & 1106.07 & 7657 & United States & 149.31 & 44270 \\
\hline Spain & 1093.27 & 47445 & Bahrain & 149.01 & 107 \\
\hline Slovenia & 1057.24 & 2114 & Iceland & 148.27 & 43 \\
\hline Australia & 829.57 & 16922 & Uruguay & 144.90 & 478 \\
\hline UK & 757.36 & 45612 & Argentina & 143.42 & 5556 \\
\hline Malta & 750.93 & 302 & China & 110.21 & 143823 \\
\hline Cyprus & 700.71 & 530 & Colombia & 109.62 & 4926 \\
\hline Netherlands & 561.34 & 9160 & Oman & 106.90 & 267 \\
\hline Portugal & 551.78 & 5820 & Chile & 69.04 & 1124 \\
\hline Sweden & 525.82 & 4744 & Belarus & 67.41 & 658 \\
\hline New Zealand & 525.17 & 2170 & South Africa & 66.54 & 3119 \\
\hline Hong Kong & 506.37 & 3449 & Jordan & 54.33 & 293 \\
\hline Ireland & 494.34 & 2055 & Thailand & 51.30 & 3231 \\
\hline Germany & 482.81 & 39816 & Trinidad \& Tob. & 49.10 & 64 \\
\hline Belgium & 459.12 & 4810 & Brazil & 45.69 & 8533 \\
\hline Japan & 420.75 & 53771 & Iran & 44.74 & 3090 \\
\hline Austria & 409.19 & 3368 & Barbados & 41.11 & 11 \\
\hline Canada & 386.98 & 12503 & Tunisia & 37.99 & 380 \\
\hline Slovakia & 380.73 & 2050 & Russia & 34.11 & 4883 \\
\hline Finland & 365.03 & 1914 & Costa Rica & 31.66 & 136 \\
\hline Estonia & 364.01 & 489 & St. Lucia & 30.34 & 4 \\
\hline France & 356.50 & 24441 & Mexico & 28.04 & 2890 \\
\hline Luxembourg & 324.06 & 147 & Panama & 25.07 & 80 \\
\hline Norway & 305.19 & 1410 & Paraguay & 24.92 & 146 \\
\hline Greece & 293.23 & 3255 & India & 22.52 & 24660 \\
\hline Korea & 290.59 & 14033 & Kazakhstan & 21.19 & 320 \\
\hline Bulgaria & 286.95 & 2220 & Indonesia & 18.45 & 4068 \\
\hline Croatia & 286.72 & 1273 & Egypt & 18.22 & 1326 \\
\hline Romania & 281.87 & 6097 & Philippines & 16.73 & 1414 \\
\hline Poland & 254.65 & 9718 & Venezuela & 16.48 & 437 \\
\hline Latvia & 244.29 & 561 & Belize & 13.71 & 3 \\
\hline
\end{tabular}

Notes: The ISO certifications as of December 2005

Sources: ISO (2006) and World Bank's WDI 
Table 1 (cont.)

List of countries in our sample and number of ISO 9000 certifications

\begin{tabular}{|c|c|c|c|c|c|}
\hline \multirow{2}{*}{ Country/Region } & \multicolumn{2}{|c|}{ ISO 9000 certifications } & \multirow{2}{*}{ Country/Region } & \multicolumn{2}{|c|}{ ISO 9000 certifications } \\
\hline & per mln inhab. & count & & per mln inhab. & count \\
\hline Morocco & 13.40 & 403 & Bangladesh & 3.72 & 570 \\
\hline Pakistan & 12.93 & 2013 & Senegal & 3.48 & 40 \\
\hline Botswana & 12.53 & 22 & Honduras & 3.37 & 22 \\
\hline Sri Lanka & 12.46 & 244 & Guatemala & 2.44 & 30 \\
\hline Guyana & 12.17 & 8 & Dominican Rep & 2.43 & 22 \\
\hline Bolivia & 11.44 & 104 & Zambia & 1.92 & 21 \\
\hline Namibia & 11.39 & 22 & Sudan & 0.89 & 32 \\
\hline Ecuador & 10.80 & 140 & Cameroon & 0.79 & 13 \\
\hline Zimbabwe & 9.91 & 129 & Malawi & 0.68 & 8 \\
\hline Peru & 7.11 & 193 & & & \\
\hline
\end{tabular}

Notes: The ISO certifications as of December 2005

Sources: ISO (2006) and World Bank's WDI 
Table 2

Variable description and summary statistics

\begin{tabular}{|c|c|c|c|c|c|c|}
\hline Variable & Definition and Source & Obs. & Mean & Std. dev. & Min & Max \\
\hline $\operatorname{Exp}_{i j t}$ & $\begin{array}{l}\text { Exports from country i to country j } \\
\text { in billions of } 2000 \text { US\$ (UN's } \\
\text { Comtrade) }\end{array}$ & 17085 & 7.559 & 49.04 & 0.000 & 2399 \\
\hline$G D P_{i t}$ & $\begin{array}{l}\text { GDP of country } i \text { in billions of } 2000 \\
\text { US\$ (World Bank's WDI) }\end{array}$ & 17085 & 356.45 & 1073.10 & 0.57 & 9760 \\
\hline$G D P_{j t}$ & $\begin{array}{l}\text { GDP of country } j \text { in billions of } 2000 \\
\text { US\$ (World Bank's WDI) }\end{array}$ & 17085 & 345.42 & 1038.42 & 0.57 & 9760 \\
\hline$P O P_{i t}$ & $\begin{array}{l}\text { Population of country } i \text { in millions } \\
\text { (World Bank's WDI) }\end{array}$ & 17085 & 58.67 & 173.83 & 0.14 & 1263 \\
\hline$P O P_{j t}$ & $\begin{array}{l}\text { Population of country } j \text { in millions } \\
\text { (World Bank's WDI) }\end{array}$ & 17085 & 57.18 & 167.16 & 0.14 & 1263 \\
\hline$I S O 9000_{i t}$ & $\begin{array}{l}\text { Number of ISO } 9000 \text { certifications } \\
\text { in country } i \text { per mln. inhabitants } \\
\text { (ISO 2002, 2006) }\end{array}$ & 17085 & 214.97 & 327.74 & 0.008 & 1672.7 \\
\hline$I S O 9000_{j t}$ & $\begin{array}{l}\text { Number of ISO } 9000 \text { certifications } \\
\text { in country } j \text { per mln. inhabitants } \\
\text { (ISO 2002, 2006) }\end{array}$ & 17085 & 202.89 & 323.61 & 0.008 & 1672.7 \\
\hline $\operatorname{Inf} r_{i t}$ & $\begin{array}{l}\text { Index of country } i \text { 's infrastructure } \\
\text { (World Bank's WDI) }\end{array}$ & 17085 & 0.622 & 0.697 & 0.006 & 5.40 \\
\hline $\operatorname{Infr} r_{j t}$ & $\begin{array}{l}\text { Index of country j's infrastructure } \\
\text { (World Bank's WDI) }\end{array}$ & 17085 & 0.610 & 0.709 & 0.006 & 5.40 \\
\hline Distance $_{i j}$ & $\begin{array}{l}\text { Great-circle distance between } \\
\text { country } i \text { and country } j \text { (Rose 2004) }\end{array}$ & 17085 & 4639.9 & 2890.6 & 62.3 & 12351.2 \\
\hline$F T A_{i j t}$ & $\begin{array}{l}\text { Existence of free trade agreement } \\
\text { between home and host nation } \\
\text { (Bergstrand's Database on } \\
\text { Economic Integration Agreements) }\end{array}$ & 17085 & 0.215 & 0.411 & 0 & 1 \\
\hline$I S O 14000_{i t}$ & $\begin{array}{l}\text { Number of ISO } 14000 \text { certifications } \\
\text { in country } i \text { per mln. inhabitants } \\
\text { (ISO 2002, 2006) }\end{array}$ & 16938 & 22.25 & 48.67 & 0.001 & 408.1 \\
\hline$I S O 14000_{j t}$ & $\begin{array}{l}\text { Number of ISO } 14000 \text { certifications } \\
\text { in country } i \text { per mln. inhabitants } \\
\text { (ISO 2002, 2006) }\end{array}$ & 16917 & 21.39 & 48.09 & 0.001 & 408.1 \\
\hline
\end{tabular}


Table 3

Gravity equation for exports: OLS Estimation results

Dependent variable: $\ln$ Exports $_{i i t}$

\begin{tabular}{|c|c|c|c|c|c|c|}
\hline Independent variables & (1) & (2) & (3) & (4) & (5) & (6) \\
\hline \multicolumn{7}{|l|}{ Base gravity: } \\
\hline Home-Nation GDP $P_{i t}$ & $\begin{array}{l}0.81 * * * \\
(0.03)\end{array}$ & $\begin{array}{l}1.79 * * * \\
(0.16)\end{array}$ & $\begin{array}{l}1.79 * * * \\
(0.17)\end{array}$ & $\begin{array}{l}1.09 * * * \\
(0.03)\end{array}$ & $\begin{array}{l}1.82 * * * \\
(0.16)\end{array}$ & $\begin{array}{l}1.82 * * * \\
(0.17)\end{array}$ \\
\hline Host-Nation $G D P_{j t}$ & $\begin{array}{l}0.80 * * * \\
(0.03)\end{array}$ & $\begin{array}{l}1.83^{* * * *} \\
(0.13)\end{array}$ & $\begin{array}{l}1.87 * * * \\
(0.14)\end{array}$ & $\begin{array}{l}0.93 * * * \\
(0.03)\end{array}$ & $\begin{array}{l}1.85 * * * \\
(0.13)\end{array}$ & $\begin{array}{l}1.90 * * * \\
(0.14)\end{array}$ \\
\hline Home-Nation POP ${ }_{i t}$ & $\begin{array}{l}0.37 * * * \\
(0.03)\end{array}$ & $\begin{array}{l}-1.42 * * * \\
(0.29)\end{array}$ & $\begin{array}{l}-1.16^{* * *} \\
(0.31)\end{array}$ & $\begin{array}{l}0.21 * * * \\
(0.03)\end{array}$ & $\begin{array}{l}-1.36^{* * *} \\
(0.28)\end{array}$ & $\begin{array}{l}-1.14 * * * \\
(0.30)\end{array}$ \\
\hline Host-Nation POP $P_{j t}$ & $\begin{array}{l}0.14 * * * \\
(0.03)\end{array}$ & $\begin{array}{l}-0.84 * * * \\
(0.29)\end{array}$ & $\begin{array}{l}-0.93 * * * \\
(0.29)\end{array}$ & $\begin{array}{l}0.02 \\
(0.03)\end{array}$ & $\begin{array}{l}-0.80 * * * \\
(0.27)\end{array}$ & $\begin{array}{l}-0.93 * * * \\
(0.28)\end{array}$ \\
\hline ISO 9000: & & & & & & \\
\hline Home-Nation ISO9000 ${ }_{i t}$ & $\begin{array}{l}0.21 * * * \\
(0.02)\end{array}$ & $\begin{array}{l}0.07 * * * \\
(0.01)\end{array}$ & $\begin{array}{l}0.05 * * * \\
(0.02)\end{array}$ & $\begin{array}{l}0.17 * * * \\
(0.02)\end{array}$ & $\begin{array}{l}0.08^{* * * *} \\
(0.01)\end{array}$ & $\begin{array}{l}0.06 * * * \\
(0.02)\end{array}$ \\
\hline Host-Nation ISO9000 ${ }_{j t}$ & $\begin{array}{l}0.03^{*} \\
(0.02)\end{array}$ & $\begin{array}{l}0.01 \\
(0.01)\end{array}$ & $\begin{array}{l}0.00 \\
(0.02)\end{array}$ & $\begin{array}{l}0.04 * * * \\
(0.02)\end{array}$ & $\begin{array}{l}0.02 \\
(0.01)\end{array}$ & $\begin{array}{l}0.01 \\
(0.01)\end{array}$ \\
\hline$I S O 9000_{i t} * I S O 9000_{j t}$ & $\begin{array}{l}0.01 * * \\
(0.00)\end{array}$ & $\begin{array}{l}0.00 \\
(0.00)\end{array}$ & $\begin{array}{l}0.00 \\
(0.00)\end{array}$ & $\begin{array}{l}0.00 \\
(0.00)\end{array}$ & $\begin{array}{l}0.00 \\
(0.00)\end{array}$ & $\begin{array}{l}0.01^{*} \\
(0.004)\end{array}$ \\
\hline Other controls: & & & & & & \\
\hline Home-Nation Infr $r_{i t}$ & $\begin{array}{l}0.15 * * * \\
(0.03)\end{array}$ & $\begin{array}{l}0.02 \\
(0.02)\end{array}$ & $\begin{array}{l}0.04 \\
(0.02)\end{array}$ & $\begin{array}{l}0.25 * * * \\
(0.03)\end{array}$ & $\begin{array}{l}0.03 \\
(0.02)\end{array}$ & $\begin{array}{l}0.04 \\
(0.025)\end{array}$ \\
\hline Host-Nation Infr $r_{j t}$ & $\begin{array}{l}0.15^{* * *} \\
(0.03)\end{array}$ & $\begin{array}{l}-0.02 \\
(0.02)\end{array}$ & $\begin{array}{l}-0.04 \\
(0.02)\end{array}$ & $\begin{array}{l}0.20 * * * \\
(0.03)\end{array}$ & $\begin{array}{l}-0.02 \\
(0.02)\end{array}$ & $\begin{array}{l}-0.04 \\
(0.02)\end{array}$ \\
\hline Distance $_{i j t}$ & $\begin{array}{l}-1.21 * * * \\
(0.03)\end{array}$ & & & $\begin{array}{l}-1.33 * * * \\
(0.03)\end{array}$ & & \\
\hline$F T A_{i j t}$ & $\begin{array}{l}0.28 * * * \\
(0.06)\end{array}$ & $\begin{array}{l}0.18 * * * \\
(0.05)\end{array}$ & $\begin{array}{l}0.20 * * * \\
(0.05)\end{array}$ & $\begin{array}{l}0.61 * * * \\
(0.06)\end{array}$ & $\begin{array}{l}0.17 * * * \\
(0.05)\end{array}$ & $\begin{array}{l}0.15 * * * \\
(0.06)\end{array}$ \\
\hline Year dummies & Yes & Yes & Yes & Yes & Yes & Yes \\
\hline Country-pair specific effects & - & $\mathrm{FE}$ & FD & - & $\mathrm{FE}$ & FD \\
\hline Multilateral resistance terms & - & - & - & Yes & Yes & Yes \\
\hline Heteroscedasticity test ${ }^{\mathrm{a}}$ & $1.65 * * *$ & $2.13 * * *$ & 1.99 & $1.62 * * *$ & $2.13 * * *$ & 1.99 \\
\hline Observations & 17085 & 16101 & 9750 & 17085 & 16101 & 9750 \\
\hline
\end{tabular}

Notes: All variables except dummy variables are in logarithms.

${ }^{* * *}$ denotes significance at $1 \%$ level, ${ }^{* *}$ at $5 \%$ level, ${ }^{*}$ at $10 \%$ level; cluster-robust standard errors in parentheses.

${ }^{a}$ The significance level in the heteroscedasticity test reflects statistical difference from 2 (and not 0 ). 
Table 4

Gravity equation for exports: IV Estimation results

Dependent variable: $\ln$ Exports $_{i j t}$

\begin{tabular}{|c|c|c|c|c|c|c|}
\hline Independent variables & (1) & (2) & (3) & (4) & (5) & (6) \\
\hline \multicolumn{7}{|l|}{ Base gravity: } \\
\hline Home-Nation GDP $P_{i t}$ & $\begin{array}{l}0.78 * * * \\
(0.07)\end{array}$ & $\begin{array}{l}1.83 * * * \\
(0.17)\end{array}$ & $\begin{array}{l}1.69 * * * \\
(0.18)\end{array}$ & $\begin{array}{l}1.06 * * * \\
(0.08)\end{array}$ & $\begin{array}{l}1.99 * * * \\
(0.17)\end{array}$ & $\begin{array}{l}1.83 * * * \\
(0.18)\end{array}$ \\
\hline Host-Nation $G D P_{j t}$ & $\begin{array}{l}0.93 * * * \\
(0.06)\end{array}$ & $\begin{array}{l}1.82 * * * \\
(0.14)\end{array}$ & $\begin{array}{l}1.87 * * * \\
(0.14)\end{array}$ & $\begin{array}{l}0.94 * * * \\
(0.06)\end{array}$ & $\begin{array}{l}1.95 * * * \\
(0.14)\end{array}$ & $\begin{array}{l}1.99 * * * \\
(0.14)\end{array}$ \\
\hline Home-Nation POP ${ }_{i t}$ & $\begin{array}{l}0.39 * * * \\
(0.06)\end{array}$ & $\begin{array}{l}-1.01 * * * \\
(0.31)\end{array}$ & $\begin{array}{l}-0.72 * * \\
(0.33)\end{array}$ & $\begin{array}{l}0.23 * * * \\
(0.07)\end{array}$ & $\begin{array}{l}-1.38 * * * \\
(0.32)\end{array}$ & $\begin{array}{l}-1.17 * * * \\
(0.34)\end{array}$ \\
\hline Host-Nation POP $P_{j t}$ & $\begin{array}{l}0.02 \\
(0.06)\end{array}$ & $\begin{array}{l}-1.02 * * * \\
(0.30)\end{array}$ & $\begin{array}{l}-0.84 * * * \\
(0.30)\end{array}$ & $\begin{array}{l}0.01 \\
(0.06)\end{array}$ & $\begin{array}{l}-1.27 * * * \\
(0.29)\end{array}$ & $\begin{array}{l}-1.17 * * * \\
(0.30)\end{array}$ \\
\hline ISO 9000: & & & & & & \\
\hline Home-Nation ISO9000 ${ }_{i t}$ & $\begin{array}{l}0.20^{* * *} \\
(0.06)\end{array}$ & $\begin{array}{l}0.10^{* * *} \\
(0.03)\end{array}$ & $\begin{array}{l}0.08 * * \\
(0.04)\end{array}$ & $\begin{array}{l}0.23 * * * \\
(0.07)\end{array}$ & $\begin{array}{l}0.10^{* *} \\
(0.04)\end{array}$ & $\begin{array}{l}0.11^{* * * *} \\
(0.04)\end{array}$ \\
\hline Host-Nation ISO9000 ${ }_{j t}$ & $\begin{array}{l}-0.15 * * * \\
(0.05)\end{array}$ & $\begin{array}{l}-0.00 \\
(0.04)\end{array}$ & $\begin{array}{l}0.002 \\
(0.04)\end{array}$ & $\begin{array}{l}0.05 \\
(0.05)\end{array}$ & $\begin{array}{l}0.0002 \\
(0.01)\end{array}$ & $\begin{array}{l}0.04 \\
(0.04)\end{array}$ \\
\hline$I S O 9000_{i t} * I S O 9000_{j t}$ & $\begin{array}{l}0.03 * * * \\
(0.004)\end{array}$ & $\begin{array}{l}0.003 \\
(0.002)\end{array}$ & $\begin{array}{l}0.01 * * * \\
(0.002)\end{array}$ & $\begin{array}{l}0.02 * \\
(0.01)\end{array}$ & $\begin{array}{l}0.05^{* * *} \\
(0.04)\end{array}$ & $\begin{array}{l}0.04 * * * \\
(0.01)\end{array}$ \\
\hline Other controls: & & & & & & \\
\hline Home-Nation Infr $r_{i t}$ & $\begin{array}{l}0.10^{* *} \\
(0.05)\end{array}$ & $\begin{array}{l}-0.03 \\
(0.03)\end{array}$ & $\begin{array}{l}-0.00 \\
(0.03)\end{array}$ & $\begin{array}{l}0.23 * * * \\
(0.05)\end{array}$ & $\begin{array}{l}0.01 \\
(0.03)\end{array}$ & $\begin{array}{l}0.02 \\
(0.03)\end{array}$ \\
\hline Host-Nation Infr $r_{j t}$ & $\begin{array}{l}0.20 * * * \\
(0.04)\end{array}$ & $\begin{array}{l}-0.02 \\
(0.03)\end{array}$ & $\begin{array}{l}-0.06^{*} \\
(0.03)\end{array}$ & $\begin{array}{l}0.21 * * * \\
(0.04)\end{array}$ & $\begin{array}{l}0.01 \\
(0.03)\end{array}$ & $\begin{array}{l}-0.049 \\
(0.033)\end{array}$ \\
\hline Distance $_{i j t}$ & $\begin{array}{l}-1.20 * * * \\
(0.03)\end{array}$ & & & $\begin{array}{l}-1.31 * * * \\
(0.03)\end{array}$ & & \\
\hline$F T A_{i j t}$ & $\begin{array}{l}0.23 * * * \\
(0.06)\end{array}$ & $\begin{array}{l}0.16^{* * *} \\
(0.05) \\
\end{array}$ & $\begin{array}{l}0.16^{* * *} \\
(0.05)\end{array}$ & $\begin{array}{l}0.58 * * * \\
(0.07)\end{array}$ & $\begin{array}{l}0.05 \\
(0.06)\end{array}$ & $\begin{array}{l}0.04 \\
(0.06)\end{array}$ \\
\hline Year dummies & Yes & Yes & Yes & Yes & Yes & Yes \\
\hline Country-pair specific effects & - & $\mathrm{FE}$ & FD & - & $\mathrm{FE}$ & FD \\
\hline Multilateral resistance terms & - & - & - & Yes & Yes & Yes \\
\hline Heteroscedasticity test ${ }^{\mathrm{a}}$ & $1.64 * * *$ & $2.12 * * *$ & 2.09 & $1.62 * * *$ & $2.13 * * *$ & 2.09 \\
\hline Observations & 19771 & 16098 & 9716 & 16771 & 16098 & 9716 \\
\hline
\end{tabular}

Notes: All variables except dummy variables are in logarithms.

${ }^{* * *}$ denotes significance at $1 \%$ level, ${ }^{* *}$ at $5 \%$ level, ${ }^{*}$ at $10 \%$ level; cluster-robust standard errors in parentheses.

${ }^{a}$ The significance level in the heteroscedasticity test reflects statistical difference from 2 (and not 0 ). 
Table 5

Average export elasticities with respect to ISO 9000 for all nations in the sample (based on results from Regression 6 in Table 4)

\begin{tabular}{|c|c|c|c|c|c|}
\hline \multirow[t]{2}{*}{ Country/Region } & \multicolumn{2}{|c|}{ Export Elasticity w.r.t.: } & \multirow[t]{2}{*}{ Country/Region } & \multicolumn{2}{|c|}{ Export Elasticity w.r.t. } \\
\hline & $\begin{array}{l}\text { Home- } \\
\text { Nation } \\
\text { Diffusion }\end{array}$ & $\begin{array}{l}\text { Host- } \\
\text { Nation } \\
\text { Diffusion }\end{array}$ & & $\begin{array}{l}\text { Home- } \\
\text { Nation } \\
\text { Diffusion }\end{array}$ & $\begin{array}{l}\text { Host- } \\
\text { Nation } \\
\text { Diffusion }\end{array}$ \\
\hline U.K. & 0.074 & 0.130 & Croatia & 0.053 & 0.017 \\
\hline Switzerland & 0.056 & 0.128 & Mauritius & 0.053 & 0.015 \\
\hline Australia & 0.058 & 0.126 & Estonia & 0.053 & 0.012 \\
\hline Singapore & 0.053 & 0.125 & Poland & 0.055 & 0.008 \\
\hline Ireland & 0.053 & 0.114 & Turkey & 0.056 & 0.005 \\
\hline New Zealand & 0.053 & 0.111 & Uruguay & 0.054 & 0.003 \\
\hline Netherlands & 0.058 & 0.109 & Oman & 0.054 & 0.002 \\
\hline Israel & 0.054 & 0.106 & Romania & 0.054 & 0.000 \\
\hline Italy & 0.068 & 0.102 & Barbados & 0.045 & 0.000 \\
\hline Sweden & 0.056 & 0.091 & Argentina & 0.057 & -0.002 \\
\hline Belgium & 0.056 & 0.090 & Brazil & 0.061 & -0.011 \\
\hline Austria & 0.055 & 0.089 & Trinidad\&Tob. & 0.054 & -0.014 \\
\hline Denmark & 0.055 & 0.087 & Lithuania & 0.054 & -0.015 \\
\hline Germany & 0.078 & 0.087 & St. Lucia & 0.054 & -0.016 \\
\hline Hong Kong & 0.055 & 0.087 & Thailand & 0.055 & -0.019 \\
\hline Slovenia & 0.053 & 0.086 & Bulgaria & 0.054 & -0.022 \\
\hline Norway & 0.055 & 0.086 & China & 0.068 & -0.023 \\
\hline Hungary & 0.053 & 0.086 & Latvia & 0.054 & -0.023 \\
\hline Finland & 0.054 & 0.083 & Jordan & 0.054 & -0.027 \\
\hline Spain & 0.061 & 0.079 & Colombia & 0.055 & -0.031 \\
\hline Luxembourg & 0.053 & 0.079 & Chile & 0.055 & -0.034 \\
\hline Malta & 0.052 & 0.078 & Mexico & 0.060 & -0.037 \\
\hline France & 0.071 & 0.076 & Tunisia & 0.054 & -0.038 \\
\hline Czech Republic & 0.053 & 0.074 & Venezuela & 0.055 & -0.041 \\
\hline Canada & 0.062 & 0.071 & Namibia & 0.054 & -0.046 \\
\hline Cyprus & 0.053 & 0.063 & Costa Rica & 0.054 & -0.048 \\
\hline Portugal & 0.054 & 0.063 & Panama & 0.054 & -0.052 \\
\hline Japan & 0.108 & 0.056 & Philippines & 0.055 & -0.054 \\
\hline Greece & 0.055 & 0.051 & Belize & 0.054 & -0.057 \\
\hline Korea & 0.060 & 0.051 & Zimbabwe & 0.054 & -0.063 \\
\hline Malaysia & 0.054 & 0.044 & India & 0.059 & -0.065 \\
\hline Iceland & 0.053 & 0.043 & Guyana & 0.054 & -0.065 \\
\hline United States & 0.146 & 0.040 & Indonesia & 0.056 & -0.068 \\
\hline Slovakia & 0.053 & 0.036 & Egypt & 0.055 & -0.070 \\
\hline South Africa & 0.055 & 0.027 & Russia & 0.057 & -0.081 \\
\hline Bahrain & 0.053 & 0.022 & Belarus & 0.054 & -0.081 \\
\hline
\end{tabular}


Table 5 (cont.)

Average export elasticities with respect to ISO 9000 for all nations in the sample (based on results from Regression 6 in Table 4)

\begin{tabular}{|c|c|c|c|c|c|}
\hline \multirow[t]{2}{*}{ Country/Region } & \multicolumn{2}{|c|}{ Export Elasticity w.r.t.: } & \multirow[t]{2}{*}{ Country/Region } & \multicolumn{2}{|c|}{ Export Elasticity w.r.t. } \\
\hline & $\begin{array}{l}\text { Home- } \\
\text { Nation } \\
\text { Diffusion }\end{array}$ & $\begin{array}{l}\text { Host- } \\
\text { Nation } \\
\text { Diffusion }\end{array}$ & & $\begin{array}{l}\text { Home- } \\
\text { Nation } \\
\text { Diffusion }\end{array}$ & $\begin{array}{l}\text { Host- } \\
\text { Nation } \\
\text { Diffusion }\end{array}$ \\
\hline Botswana & 0.054 & -0.083 & Honduras & 0.055 & -0.137 \\
\hline Paraguay & 0.054 & -0.085 & Zambia & 0.055 & -0.139 \\
\hline Sri Lanka & 0.054 & -0.088 & Senegal & 0.055 & -0.141 \\
\hline Morocco & 0.055 & -0.093 & Kazakhstan & 0.055 & -0.144 \\
\hline Iran & 0.055 & -0.093 & Guatemala & 0.055 & -0.148 \\
\hline Ecuador & 0.055 & -0.094 & Cameroon & 0.055 & -0.171 \\
\hline Peru & 0.055 & -0.095 & Malawi & 0.055 & -0.184 \\
\hline Bolivia & 0.055 & -0.110 & Bangladesh & 0.056 & -0.193 \\
\hline Pakistan & 0.055 & -0.111 & Sudan & 0.056 & -0.207 \\
\hline Dominican Rep & 0.055 & -0.122 & & & \\
\hline
\end{tabular}

\section{Table 6}

Summary statistics of export elasticities with respect to ISO 9000 across all country-pairs in the sample (based on results from Regression 6 in Table 4)

\begin{tabular}{llccccc}
\hline \hline & & Obs. & Mean & Std. dev. & Min & Max \\
\hline Home-Nation & Partial effect & 9671 & 0.270 & 0.081 & -0.0002 & 0.392 \\
Diffusion & Total effect & 9671 & 0.075 & 0.079 & -0.192 & 0.247 \\
\hline Host-Nation & Partial effect & 9692 & 0.219 & 0.073 & -0.063 & 0.329 \\
Diffusion & Total effect & 9692 & 0.024 & 0.071 & -0.255 & 0.183 \\
\hline
\end{tabular}




\section{Figure 1}

Elasticity of exports with respect to home-nation diffusion (based on results from Regression 6 in Table 4)

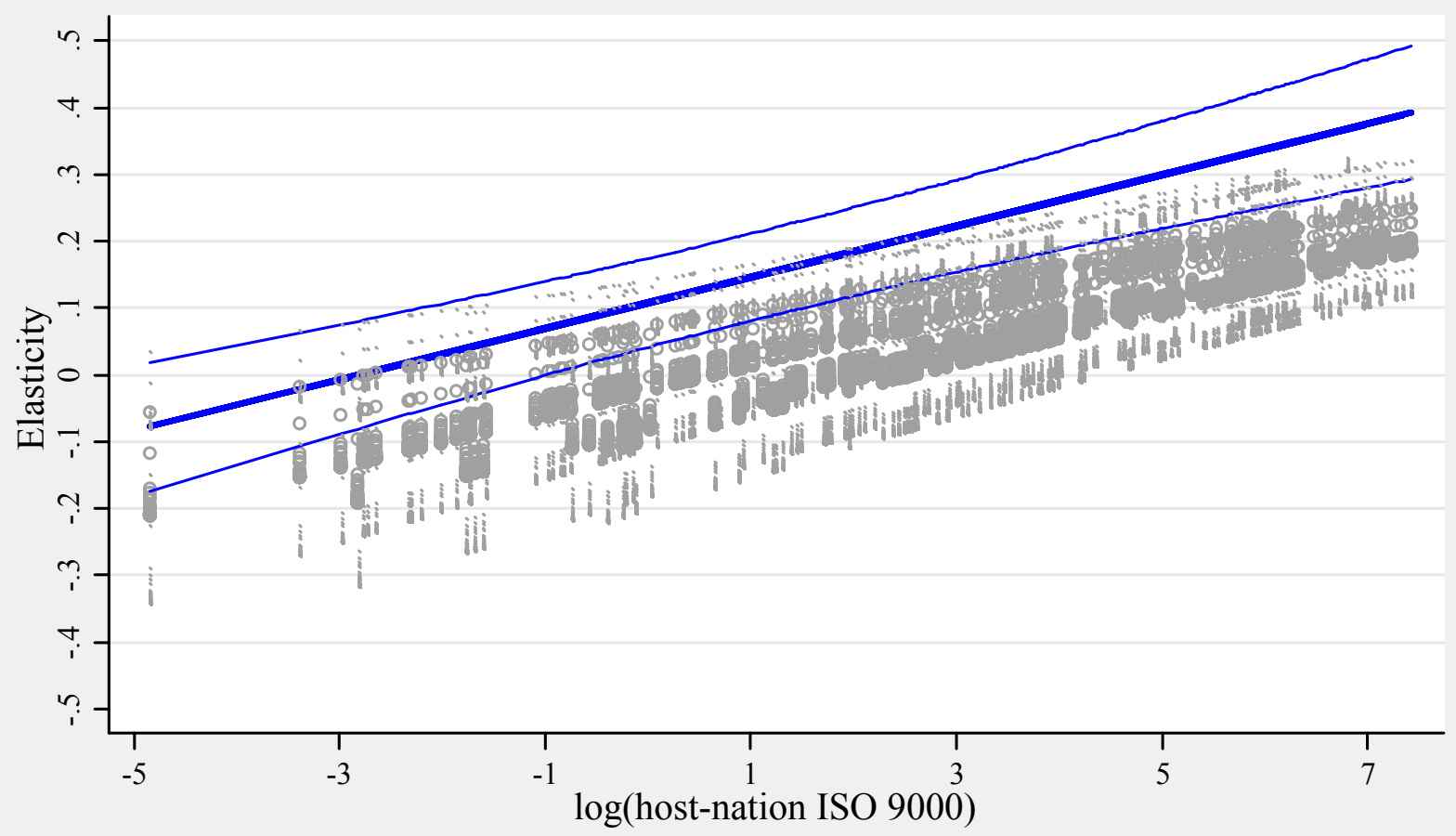

\begin{tabular}{lll}
\hline Partial Effect & $\circ$ Total Effect \\
\hline Partial Effect: $90 \%$ Lower Bound & $\cdot$ Total Effect: $90 \%$ Lower Bound \\
Partial Effect: $90 \%$ Upper Bound & $\cdot$ Total Effect: $90 \%$ Upper Bound
\end{tabular}


Figure 2

Elasticity of exports with respect to host-nation diffusion (based on results from Regression 6 in Table 4)

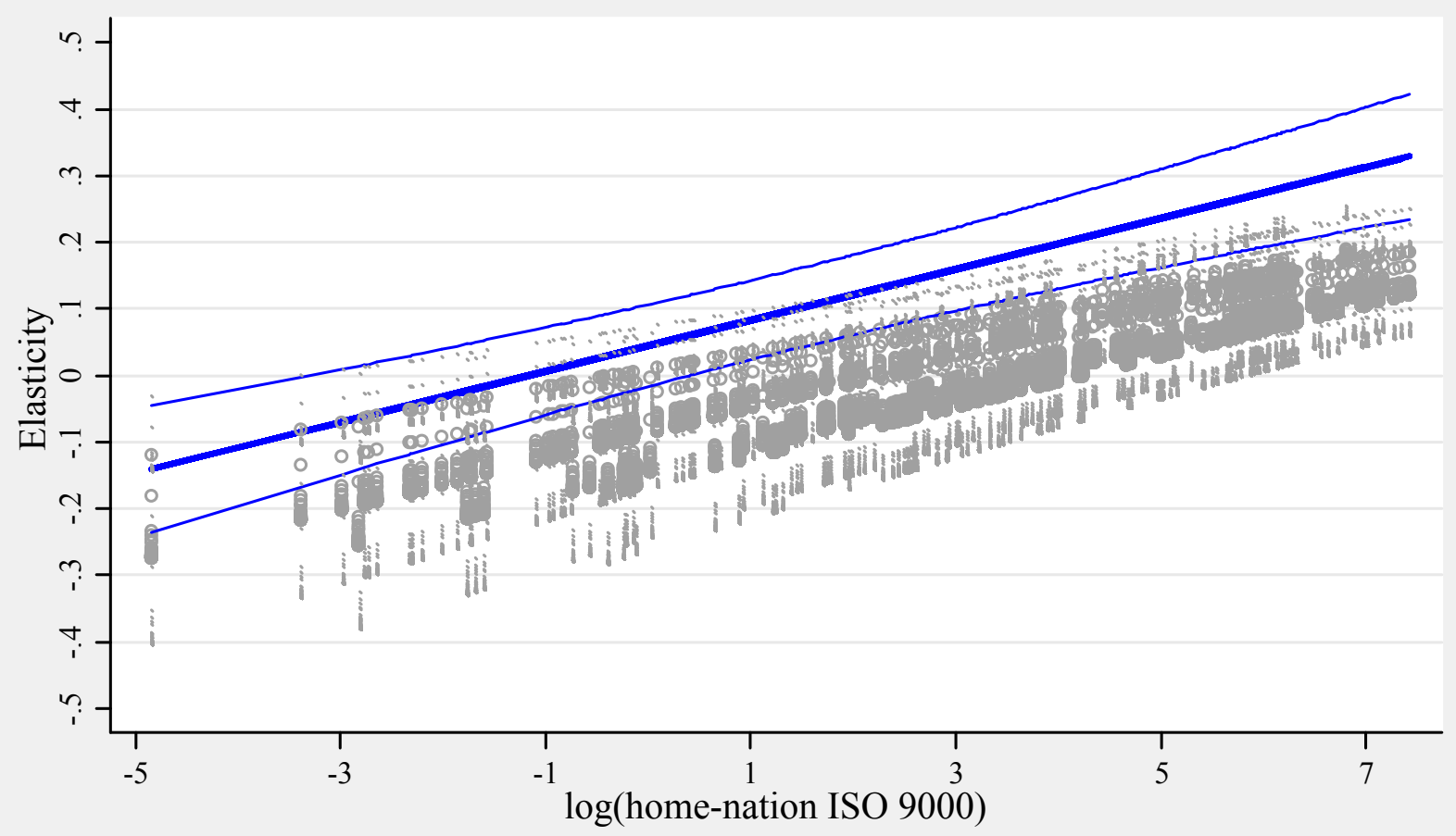

\begin{tabular}{|c|c|}
\hline Partial Effect & - Total Effect \\
\hline Partial Effect: 90\% Lower Bound & Total Effect: 90\% Lower Bound \\
\hline Partial Effect: 90\% Upper Bound & Total Effect: $90 \%$ Upper Bound \\
\hline
\end{tabular}




\section{Appendix}

In order to fully factor the role of ISO 9000 in international trade we introduce the theorydriven multilateral resistance (MR) terms in our gravity model (1) - (2) following Baier and Bergstrand (2009). In particular, we define:

$$
\begin{aligned}
\text { MRISO9000 }_{i j t} & =\sum_{k} \theta_{k t} \ln \left(I S O 9000_{i t}\right) \ln \left(I S O 9000_{k t}\right)+\sum_{m} \theta_{m t} \ln \left(I S O 9000_{m t}\right) \ln \left(I S O 9000_{j t}\right) \\
& -\sum_{k} \sum_{m} \theta_{k t} \theta_{m t} \ln \left(I S O 9000_{m t}\right) \ln \left(I S O 9000_{k t}\right)
\end{aligned}
$$

where $\theta_{i t}=\frac{G D P_{i t}}{\sum_{n} G D P_{n t}}$ is the fraction of country i's GDP in the world GDP, and where $m, k$ and $n$ allow for convenient expression. The MR terms for the distance and the FTA variables are defined analogously. These three MR terms (distance, FTA presence, and common-language) are included in regression 3 (table 3 and table 4) and their coefficients are restricted to respectively equal $-\phi_{1},-\phi_{2}$, and $-\phi_{3}$; i.e., they have identical but oppositely-signed coefficient-estimates as compared to the coefficient estimates for the three bilateral trade cost measures defined in equation (2).

With the entry of these new variables in to regression 3 , the coefficients estimates on the bilateral trade cost measures (distance, FTA and ISO 9000 common-language) can thus be interpreted as pure partial effects. We calculate the total effects as follows:

$$
\begin{aligned}
& \frac{\partial \ln \operatorname{Exp}_{i j t}}{\partial \ln \left(I S O 9000_{i t}\right)}=\hat{\gamma}_{1}+\hat{\phi}_{3} \ln \left(I S O 9000_{j t}\right)-\hat{\phi}_{3} \frac{\partial M R I S O_{i j t}}{\partial \ln \left(I S O 9000_{i t}\right)}, \\
& \frac{\partial \ln \operatorname{Exp}_{i j t}}{\partial \ln \left(I S O 9000_{j t}\right)}=\hat{\gamma}_{2}+\hat{\phi}_{3} \ln \left(I S O 9000_{i t}\right)-\hat{\phi}_{3} \frac{\partial M R I S O_{i j t}}{\partial \ln \left(I S O 9000_{j t}\right)} .
\end{aligned}
$$

The total effects calculated in this fashion are shown in tables 5 and 6, as well as in figures 1 and 2. We do not compute the total effects for distance and FTA presence, as these constructs are not the main focus of this paper. They could, however, be calculated analogously. 
Table A1. First-stage estimation results

\begin{tabular}{|c|c|c|c|c|c|c|}
\hline Equation: & (1) & (2) & (3) & (4) & (5) & (6) \\
\hline Dependent variable: & $\begin{array}{l}\text { Home- } \\
\text { Nation } \\
{\text { ISO } 9000_{i t}}\end{array}$ & $\begin{array}{l}\text { Host- } \\
\text { Nation } \\
\text { ISO9000 }_{i t}\end{array}$ & $\begin{array}{l}I_{\text {ISO9000 }} \\
\text { ISO }_{i t} \\
\end{array}$ & $\begin{array}{l}\text { Home- } \\
\text { Nation } \\
\text { ISO9000 }_{i t}\end{array}$ & $\begin{array}{l}\text { Host- } \\
\text { Nation } \\
\text { ISO9000 }_{i t}\end{array}$ & $\begin{array}{l}I_{*} O 9000_{i t} \\
I S O 9000_{i t}\end{array}$ \\
\hline Home-Nation $G D P_{i t}$ & $\begin{array}{l}0.795 * * * \\
(0.019)\end{array}$ & $\begin{array}{l}-0.038^{* *} \\
(0.015)\end{array}$ & $\begin{array}{l}1.097 * * * \\
(0.103)\end{array}$ & $\begin{array}{l}0.837 * * * \\
(0.019)\end{array}$ & $\begin{array}{l}-0.012 \\
(0.015)\end{array}$ & $\begin{array}{l}-1.047 * * * \\
(0.103)\end{array}$ \\
\hline Host-Nation $G D P_{j t}$ & $\begin{array}{l}-0.044 * * * \\
(0.014)\end{array}$ & $\begin{array}{l}0.884 * * * \\
(0.021)\end{array}$ & $\begin{array}{l}1.611^{* * *} \\
(0.104)\end{array}$ & $\begin{array}{l}-0.020 \\
(0.014)\end{array}$ & $\begin{array}{l}0.900 * * * \\
(0.020)\end{array}$ & $\begin{array}{l}-1.005^{* * *} \\
(0.095)\end{array}$ \\
\hline Home-Nation POP $i t$ & $\begin{array}{l}-0.643^{* * *} \\
(0.021)\end{array}$ & $\begin{array}{l}0.042 * * \\
(0.017)\end{array}$ & $\begin{array}{l}-0.618^{* * *} \\
(0.111)\end{array}$ & $\begin{array}{l}-0.668^{* * *} \\
(0.021)\end{array}$ & $\begin{array}{l}0.022 \\
(0.017)\end{array}$ & $\begin{array}{l}1.314 * * * \\
(0.113)\end{array}$ \\
\hline Host-Nation POP ${ }_{j t}$ & $\begin{array}{l}0.037 * * \\
(0.016)\end{array}$ & $\begin{array}{l}-0.718^{* * * *} \\
(0.023)\end{array}$ & $\begin{array}{l}-1.130^{* * * *} \\
(0.114)\end{array}$ & $\begin{array}{l}0.015 \\
(0.016)\end{array}$ & $\begin{array}{l}-0.735^{* * *} \\
(0.023)\end{array}$ & $\begin{array}{l}1.101^{* * *} \\
(0.105)\end{array}$ \\
\hline Home-Nation Infr $r_{i t}$ & $\begin{array}{l}0.580 * * * \\
(0.021)\end{array}$ & $\begin{array}{l}0.009 \\
(0.016)\end{array}$ & $\begin{array}{l}2.059 * * * \\
(0.112)\end{array}$ & $\begin{array}{l}0.572 * * * \\
(0.021)\end{array}$ & $\begin{array}{l}-0.002 \\
(0.016)\end{array}$ & $\begin{array}{l}-0.145 \\
(0.116)\end{array}$ \\
\hline Host-Nation Infr $r_{j t}$ & $\begin{array}{l}0.005 \\
(0.014)\end{array}$ & $\begin{array}{l}0.487 * * * \\
(0.024)\end{array}$ & $\begin{array}{l}1.680 * * * \\
(0.118)\end{array}$ & $\begin{array}{l}-0.006 \\
(0.014)\end{array}$ & $\begin{array}{l}0.476^{* * *} \\
(0.024)\end{array}$ & $\begin{array}{l}-0.199^{*} \\
(0.109)\end{array}$ \\
\hline Distance $_{i j t}$ & $\begin{array}{l}-0.032 * * \\
(0.014)\end{array}$ & $\begin{array}{l}-0.027^{*} \\
(0.014)\end{array}$ & $\begin{array}{l}-0.508 * * * \\
(0.082)\end{array}$ & $\begin{array}{l}-0.206^{* * *} \\
(0.014)\end{array}$ & $\begin{array}{l}-0.120^{* * * *} \\
(0.015)\end{array}$ & $\begin{array}{l}0.181 * * \\
(0.071)\end{array}$ \\
\hline$F T A_{i j t}$ & $\begin{array}{l}0.093 * * * \\
(0.028)\end{array}$ & $\begin{array}{l}0.138^{* * * *} \\
(0.029)\end{array}$ & $\begin{array}{l}2.163 * * * \\
(0.170)\end{array}$ & $\begin{array}{l}-0.264^{* * * *} \\
(0.029)\end{array}$ & $\begin{array}{l}-0.148^{* * *} \\
(0.030)\end{array}$ & $\begin{array}{l}3.118^{* * *} \\
(0.146)\end{array}$ \\
\hline Home-Nation ISO14000 ${ }_{i t}$ & $\begin{array}{l}0.200 * * * \\
(0.007)\end{array}$ & $\begin{array}{l}0.023 * * * \\
(0.007)\end{array}$ & $\begin{array}{l}1.238 * * * \\
(0.044)\end{array}$ & $\begin{array}{l}0.192 * * * \\
(0.007)\end{array}$ & $\begin{array}{l}0.021 * * * \\
(0.007)\end{array}$ & $\begin{array}{c}-0.082 * \\
(0.043)\end{array}$ \\
\hline Host-Nation ISO14000 $j t$ & $\begin{array}{l}0.017 * * \\
(0.007)\end{array}$ & $\begin{array}{l}0.231 * * * \\
(0.007)\end{array}$ & $\begin{array}{l}1.289^{* * *} \\
(0.043)\end{array}$ & $\begin{array}{l}0.012 * \\
(0.007)\end{array}$ & $\begin{array}{l}0.228 * * * \\
(0.007)\end{array}$ & $\begin{array}{l}-0.094 * * \\
(0.041)\end{array}$ \\
\hline$I S O 14000_{i t} * I S O 14000_{j t}$ & $\begin{array}{l}-0.009 * * * \\
(0.001)\end{array}$ & $\begin{array}{l}-0.013 * * * \\
(0.002)\end{array}$ & $\begin{array}{l}0.498 * * * \\
(0.010)\end{array}$ & $\begin{array}{l}0.003 \\
(0.002)\end{array}$ & $\begin{array}{l}0.007 * * * \\
(0.002)\end{array}$ & $\begin{array}{l}0.388 * * * \\
(0.012)\end{array}$ \\
\hline Year dummies & Yes & Yes & Yes & Yes & Yes & Yes \\
\hline Country-pair fixed effects & - & - & - & - & - & - \\
\hline $\begin{array}{l}\text { Multilateral resistance } \\
\text { terms }\end{array}$ & - & - & - & Yes & Yes & Yes \\
\hline Observations & 16771 & 16771 & 16771 & 16771 & 16771 & 16771 \\
\hline F-statistics & $272.17 * * *$ & $326.63 * * *$ & $1638.3 * * *$ & $252.15^{* * *}$ & $330.70 * * *$ & $386.09 * * *$ \\
\hline
\end{tabular}

Notes: All variables except dummy variables are in logarithms.

${ }^{* * *}$ denotes significance at $1 \%$ level, ${ }^{* *}$ at $5 \%$ level, ${ }^{*}$ at $10 \%$ level; cluster-robust standard errors in parentheses. 